\title{
Shallow burial dolomitisation of Middle-Upper Permian paleosols in an extensional tectonic context (SE Iberian Basin, Spain): Controls on temperature of precipitation and source of fluids
}

\author{
M. Isabel Benito ${ }^{\mathrm{a}, *}$, Raúl De la Horra ${ }^{\mathrm{a}}$, José López-Gómez ${ }^{\mathrm{a}}$, José F. Barrenechea ${ }^{\mathrm{b}}$, \\ Javier Luque ${ }^{\mathrm{b}}$, Alfredo Arche ${ }^{\mathrm{a}}$ \\ a Departamento de Estratigrafia, Instituto de Geología Económica/IGE UCM-CSIC, Facultad de Ciencias Geologicas, Universidad Complutense. 28040 Madrid, Spain \\ ${ }^{b}$ Departamento de Cristalografia y Mineralogía. IGE UCM-CSIC, Facultad de Ciencias Geológicas, Universidad Complutense. 28040 Madrid, Spain
}

Keywords:

Permian paleosols

Iberian Ranges

Dolomite

Magnesite

$\mathrm{C}, \mathrm{O}, \mathrm{Sr}$ isotopes

\section{A B S T R A C T}

This work is focused on carbonate paleosols developed in three stratigraphic sections (Iandete, Talayuelas and Henarejos) of the Middle-Late Permian Alcotas Formation in the SE Iberian Basin. The Alcotas Formation, of alluvial origin, was deposited in semi-connected half-grabens developed during the early stages of the Permian-Triassic rifting stage that affected the Iberian Basin. The studied sections were located in two of these half-grabens, the Henarejos section being much closer to the basin boundary fault than the other two sections. The mineralogy and texture of the carbonate precursor of paleosols in the three studied sections are not preserved because original carbonate is replaced by coarse crystals of dolomite and/or magnesite. Dolomite crystals are typically euhedral, displaying rhombohedral shapes and reddish luminescence, although in the Henarejos section dolomite displays non-planar boundaries and frequently saddle habit. Micas are deformed and adapted to dolomite crystals, which, in turn, are affected by stylolites, suggesting that dolomite precipitated before mechanical and chemical compaction. Carbon and oxygen isotopic compositions of dolomite from the three sections show different values $\left({ }^{13} \mathrm{C}_{\mathrm{VP}} \mathbf{m}\right.$ mean values $=-6.7 \%$, $-5.5 \%$ and $-7.5 \% ; \mathbf{6}^{18} \mathrm{OVp}$ mean values $=-4.0 \%$; $-5.6 \%$ and $-8.2 \%$, at landete, Talayuelas and Henarejos sections, respectively). The ${ }^{87} \mathrm{Sr} /{ }^{86} \mathrm{Sr}$ ratios are similar in the three sections yielding values between 0.71391 and 0.72213 . The petrographic and geochemical features of dolomite in the three studied sections suggest precipitation from similar fluids and during shallow burial diagenesis. Assuming that the minimum temperature for dolomite precipitation in the Henarejos section was $60^{\circ} \mathrm{C}$ (as suggested by the presence of non-planar saddle habit), and that the dolomitizing fluid had similar $8^{18} \mathrm{O}$ values at the three localities, then dolomite in the Talayuelas and landete sections precipitated at temperatures around 16 and $25^{\circ} \mathrm{C}$ cooler, respectively. In addition, the $8^{18} \mathrm{O}$ VSMOW values of the water from which dolomite precipitated would have ranged between -0.3 and $-2.9 \%$. Dolomite is partially or totally replaced by non- to dark dull luminescent magnesite in the Landete and Talayuelas sections. Magnesite crystals are affected

mean values are -6.5 and $-6.0 \%$ and the $8^{18} \mathrm{O} \mathrm{VP}$ s mean values are -6.7 and $-7.8 \%$, in the Landete and Talayuelas sections, respectively. The ${ }^{87} \mathrm{Sr}{ }^{\beta 6} \mathrm{Sr}$ ratios of magnesite are similar in both sections yielding values between 0.71258 and 0.72508 . This suggests that they probably precipitated from similar fluids during progressive burial and at higher temperatures than dolomites at the same sections. Assuming that magnesite precipitated from a fluid with similar $8^{18} \mathrm{O}$ values in both sections, then it had to precipitate at a temperature around $8^{\circ} \mathrm{C}$ higher in Talayuelas than in the Landete section. Dolomitisation and magnesite precipitation probably occurred via reflux of saline to hypersaline brines from the overlying Mid-Iate Triassic Muschelkalk and/or Keuper facies. The temperatures inferred for dolomite precipitation, however, are too high for shallow burial if a normal geothermal gradient is applied. Thus, it can be inferred that saline fluids were heated as they flowed through the syn-sedimentary extensional faults that controlled Middle Permian to Middle Triassic sedimentation; consequently fluids would have been at higher temperatures near the Henarejos area, which was closer to the basin boundary fault than at the Talayuelas and Landete areas, which were situated further away. This contention is in agreement with recent studies which demonstrate that an important thermal event took place during Late Triassic-Early Jurassic times in the Iberian Peninsula. 


\section{Introduction}

The study of paleosols developed in redbeds has been used for explaining some local aspects of the evolution of Permian and Triassic basins in Spain (e.g. Alonso-Zarza et al., 1999; Gómez-Gras and AlonsoZarza, 2003; De la Horra et al., 2008). Paleosols studied in this paper are a distinctive feature of the Middle-Iate Permian Alcotas Formation and their presence has been previously reported in this unit and in its lateral equivalent formations in the Iberian Ranges by different authors (e.g. Ramos, 1979; López-Gómez, 1985; Pérez-Arlucea, 1985). From a paleoenvironmental point of view, De la Horra et al. (2008) described and classified the different pedogenic horizons found in the Alcotas Formation and related them to the sedimentary and biotic changes observed in the last stages of the Permian. This work is focused on carbonate paleosols developed in the lower part of the Alcotas Formation, which were diagenetically altered as the carbonate precursor was replaced by dolomite and/or magnesite (Benito et al., 2005).

Dolomite and magnesite precipitation may occur as a primary phase or as a replacement under surface conditions, during burial or associated with hydrothermal fluids, metamorphism, and metasomatism of carbonate, evaporite, metamorphic and ultramafic rocks (e.g. Möller, 1989; Pohl, 1990; Warren, 2000; Deelman, 2008 and references therein). Specifically, dolomite and magnesite precipitation in siliciclastic continental deposits have been previously described in other Permian and Triassic basins as relatively early diagenetic phases (e.g. Niedermayr et al, 1989; Purvis, 1989; 1992; Spötl and Burns, 1994), or as early to late diagenetic precipitates (Rossi et al. 2002). In these studies, magnesite precipitation has been related to $\mathrm{Mg}$-rich fluids coming from overlying evaporitic units (e.g. Niedermayr et al., 1989; Purvis, 1989; Rossi et al, 2002) or coming from the weathering of dolomite and magnesite deposits in the catchment area (e.g. Spötl and Burns, 1994).

The aim of this work is to study the diagenetic evolution of carbonate paleosols of the Alcotas Formation in three different, but relatively close, stratigraphic sections, in order to characterise the diagenetic environment of dolomite and magnesite precipitation, to estimate the temperature of precipitation in each section, and to relate it to the synsedimentary extensional fault system developed during the Permian-Triassic rifting stage of the Iberian Basin (Fig. 1).

\section{Materials and methods}

Three selected stratigraphic sections of the Alcotas Formation have been studied in detail. A total of 140 rock samples of carbonate paleosols and nodules were collected for laboratory studies. For each representative sample, a polished and uncovered thin section was prepared to $30 \mu \mathrm{m}$ thickness for petrographic and elemental analyses utilising standard petrographic techniques, cathodoluminescence and SEM petrography. For 65 samples, a polished $150-200 \mu \mathrm{m}$ thick section, matching the $30 \mu \mathrm{m}$ thin section, was prepared for isotopic and elemental analyses. Cathodoluminescence (CL) examination was carried out using a Technosyn cold cathodoluminescence unit operating at $20-25 \mathrm{kV}$ with $300-400 \mu \mathrm{A}$ beam current. Following examination with $\mathrm{CI}$, thin sections were stained with Alizarin Red S and potassium ferricyanide (Dickson, 1966).

Elemental analyses for $\mathrm{Ca}, \mathrm{Mg}, \mathrm{Sr}, \mathrm{Na}, \mathrm{Mn}$ and Fe were performed on a JEOL JXA-8900 M WD/ED electron microprobe at the University Complutense of Madrid with an accelerating voltage of $15 \mathrm{kV}$ and a spot size of $5 \mu \mathrm{m}$. The detection limits were $120 \mathrm{ppm}$ for $\mathrm{Mg}, 140 \mathrm{ppm}$ for Ca, $150 \mathrm{ppm}$ for Sr, $120 \mathrm{ppm}$ for $\mathrm{Na}, 200 \mathrm{ppm}$ for $\mathrm{Mn}$, and $275 \mathrm{ppm}$ for Fe. To allow direct comparison with isotopic analyses, elemental analyses were made on the same thick sections.

Bulk sample mineralogy was also characterised by $\mathrm{X}$-ray diffraction (XRD) analysis of 10 samples after grinding and homogenization of the samples to $<53 \mu \mathrm{m}$. Random-oriented powders were examined on a
Siemens D500 diffractometer, using Cu-K $\alpha$ at $30 \mathrm{kV}$ and $40 \mathrm{~mA}$, a step size of $0.03\left({ }^{\circ} 2 \theta\right)$, and time per step of $1 \mathrm{~s}$ (scan rate of $1.8^{\circ} 2 \theta / \mathrm{min}$ ).

For isotope analyses, carbonates were microsampled from thick sections using a microscope-mounted drilling system after CL examination. Sampling areas ranged from 300 to $500 \mu \mathrm{m}$ in diameter, resulting in the recovery of 100-150 $\mu \mathrm{g}$ powdered samples. Analyses for $\delta^{13} \mathrm{C}$ and $\delta^{18} \mathrm{O}$ values were performed in the Stable Isotope Laboratory at the University of Michigan. All sample powders were roasted at vacuum conditions for $1 \mathrm{~h}$ at $200{ }^{\circ} \mathrm{C}$ to remove volatile organic contaminants, then reacted at $73{ }^{\circ} \mathrm{C}$ during 12 and 22 min (f or dolomite and magnesite, respectively) in an automated carbonate reaction system (CarboKiel-III) coupled directly to the inlet of a Finnigan MAT 253 gas ratio mass spectrometer. Isotopic ratios were corrected for ${ }^{17} \mathrm{O}$ contribution and are reported in per mil notation relative to the VPDB standard. Values were calibrated utilising NBS 19 as the primary standard, and analytical precision was monitored by daily analysis of NBS powdered carbonate standards. Precision was better than $0.1 \%$ for both $\delta^{13} \mathrm{C}$ and $\delta^{18} \mathrm{O}$ measurements.

The ${ }^{87} \mathrm{Sr} /{ }^{86} \mathrm{Sr}$ composition was determined on an automated multicollector TIMS VG SECTOR 549 mass spectrometer at the Geochronology and Isotope Geochemistry Centre of the Complutense University of Madrid. Carbonate minerals were microsampled from thick sections using a microscope-mounted drilling system after CL examination. Powder was dissolved in $5 \mathrm{ml}$ of $2.5 \mathrm{~N} \mathrm{HCl}$ and they were subsequently centrifuged at $4000 \mathrm{rpm}$ during $10 \mathrm{~min}$, in order to eliminate the solid residue, basically consisting of silicate minerals. Samples were then redissolved in $2.5 \mathrm{~N} \mathrm{HCl}$ solution and after $\mathrm{Sr}$ pre-concentration by standard column chromatography methods, samples were then dried. Silicate samples were powdered and first decomposed in $4 \mathrm{ml} \mathrm{HF}$ and $2 \mathrm{ml} \mathrm{HNO}$, in Teflon digestion bombs during $48 \mathrm{~h}$ at $120{ }^{\circ} \mathrm{C}$ and finally in $6 \mathrm{M} \mathrm{HCl}$. Srwas separated by standard ion exchange procedures using Bio-Rad AG50 $\times 12$ cation exchange resin. Internal precision was always better than 4-6 $10^{-6}$. Analytical precision was monitored by analysis of the NBS-987 standard. Analytical uncertainties are estimated to be $0.01 \%$ for ${ }^{87} \mathrm{Sr} /{ }^{86} \mathrm{Sr}$ ratios and $0.1 \%$ for the ${ }^{87} \mathrm{Rb} /{ }^{86} \mathrm{Sr}$. Replicate analyses of the NBS-987 Sr-isotope standard yielded an average ${ }^{87} \mathrm{Sr} /{ }^{86} \mathrm{Sr}$ ratio of $0.710247 \pm 0.000024$.

\section{Geological and stratigraphic settings}

The studied sections of the Middle-Upper Permian Alcotas Formation selected for this study are situated close to the localities of Landete, Henare jos and Talayuelas southeastwards of the presentday Iberian Ranges (Fig. 1). The Iberian Basin started to develop as a rift basin during the Early Permian and experienced several extensional periods during the Middle-Late Permian and the Mesozoic, mainly during the Olenekian, Oxfordian-Kimmeridgian and Berriasian, as well as two compressive events that caused folding and thrusting during the Cenozoic, resulting in the present-day Iberian Ranges (Sopeñ a et al., 1988; Salas and Casas, 1993; Arche and López-Gómez, 1996; López-Góme z et al., 2002). During the MiddleLate Permian the Iberian Basin was bounded by highs that also subdivided the basin and conditioned its development and sedimentary infill. Sedimentation was of alluvial origin and its sedimentological, mineralogical, and tectonic evolution have been studied in detail in previous works (Ramos et al., 1986; Sopeña et al., 1988; López-Gómez and Arche, 1993; Arche and López-Gómez, 1996, 2005; Alonso-Azcárate et al., 1997; Benito et al, 2005; De la Horra et al., 2008).

The Middle-Upper Permian strata of the SE Iberian Ranges crop out in the nucleus of anticlines with NW-SE oriented main axis (Fig. 1B). However, secondary NE-SW faults separate these anticlines and can also cut some of their flanks. The NW-SE oriented faults, parallel to the axis of the anticlines, were mostly reactivated from older fractures of Variscan origin and acted as extensional fractures during the different phases of the rifting evolution. The subordinated NE-SW fault system 


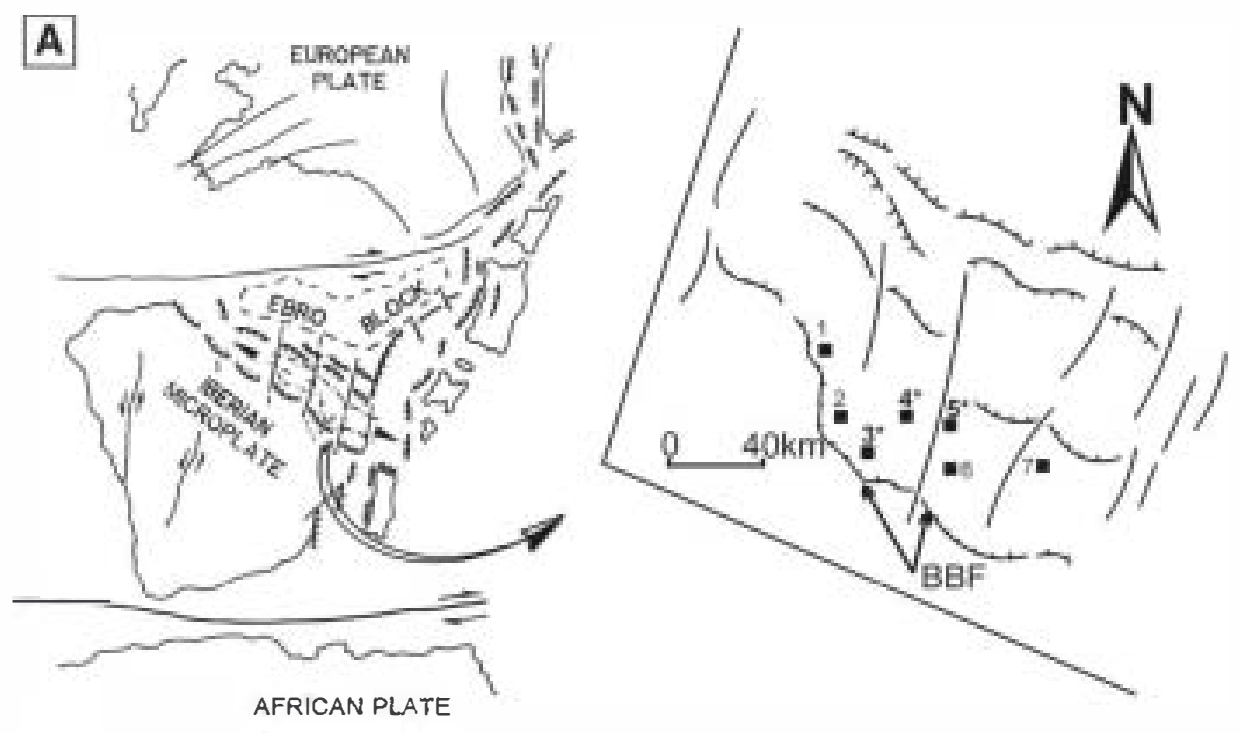

B

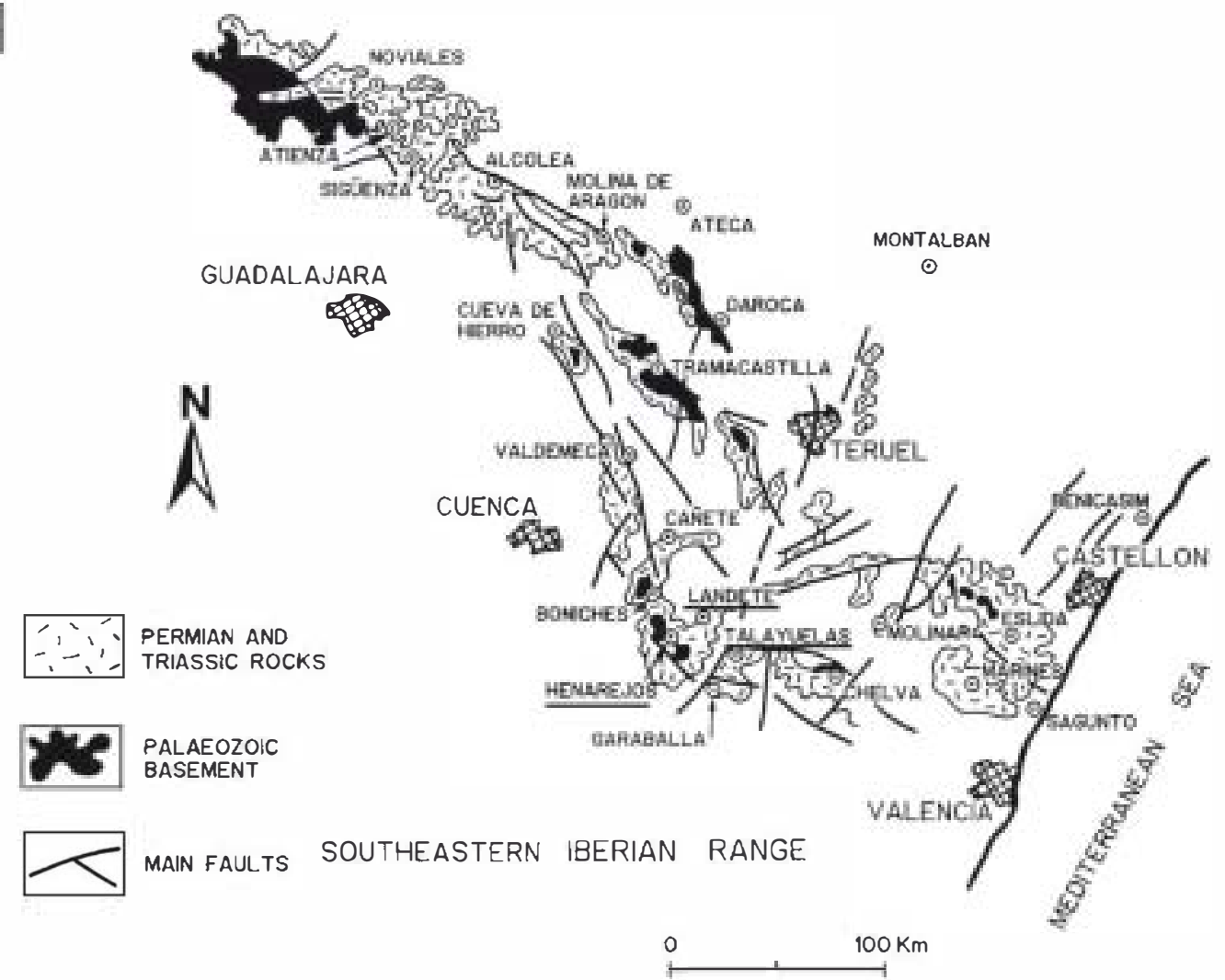

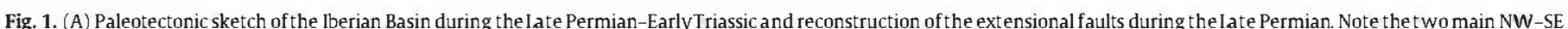

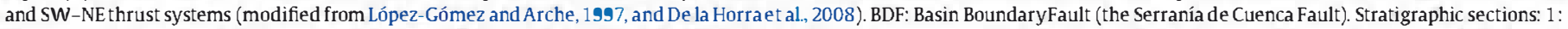

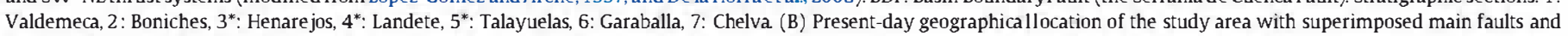
localities (the localities of the three studied sections are underlined).

mainly corresponds to transfer faults resulting from the accommodation during the development of the Iberian Basin rifting stages (Arche and López-Gómez, 1996; López-Gómez et al., 2010) (Fig. 1). These latter secondary faults separated semi-connected neighbouring half-grabens that represent segments of a main NW-SE structural lineation of the basin. The stratigraphic sections studied in this work are situated in two of these semi-connected half-grabens (Fig.1A).

The period of sedimentation from the Middle-Iate Permian to the Early-Middle Triassic in the study area is affected by two main pulses of rifting separated by an unconformity (Fig. 2). The earlier Middle-Iate Permian pulse is represented by two units of alluvial origin (López-Gómez and Arche, 1993; Arche and López-Gómez, 1999): the Boniches Formation and the overlying Alcotas Formation. The second and younger pulse of rif ting is constituted by the Cañizar Formation of continental origin, and with a maximum thickness in the area of $156 \mathrm{~m}$ (Vargas et al., 2009). The Cañizar Formation is Olenekian (Early Triassic) in age, although the uppermost part is of early Anisian (Middle Triassic) age (Doubinger et al., 1990; Sopeña et al., 1995; Bourquin et al, 2007). The Cañizar Formation is overlain by Middle Triassic marine carbonate deposits (Muschelkalk facies) and subsequently by clays, marls and evaporites of the Upper Triassic (Keuper facies); in the study area, the estimated thicknesses of these two units are $225 \mathrm{~m}$ and $220 \mathrm{~m}$, respectively (Vargas et al., 2009). 


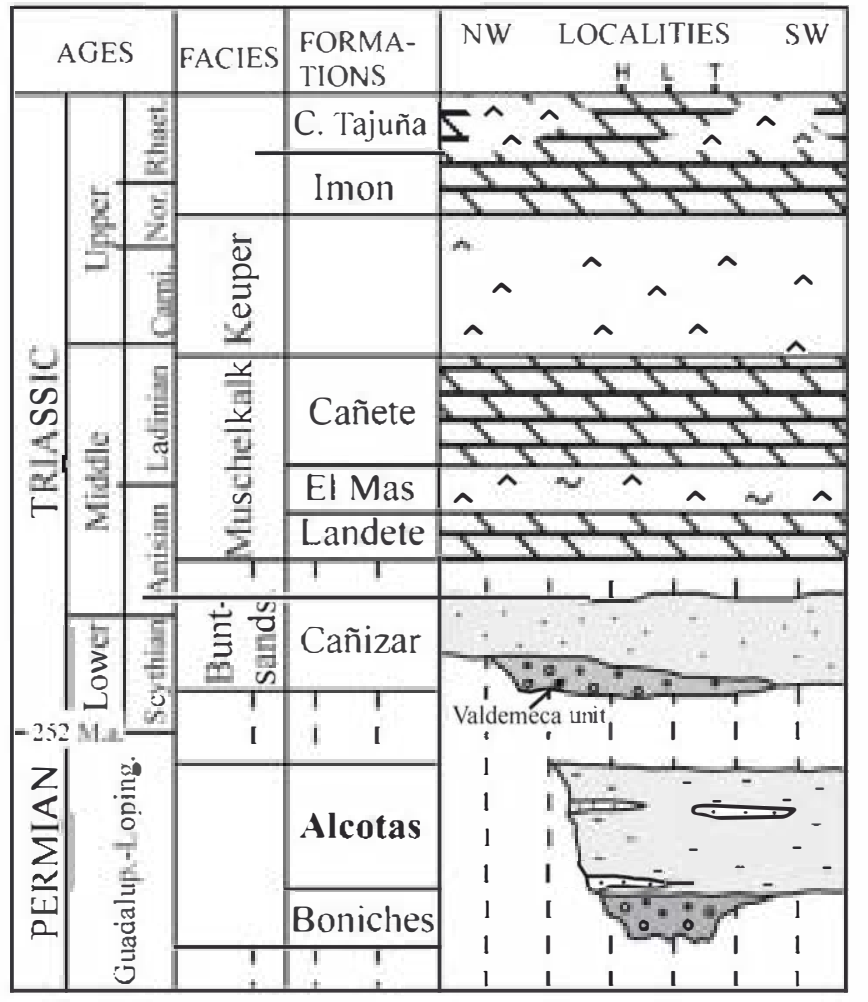

$\because 0$ CONGLOMERATE POLOMITE

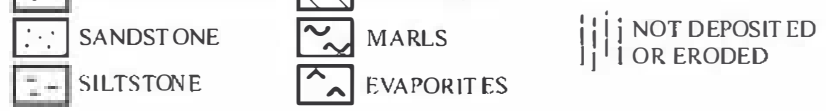

Fig. 2. Permian and Triassic stratigraphic succession in the study area ( $H, L$ and $T$ correspond to the location of Henare jos, Landete and Talayuelas sections, respectively).

The stratigraphy, sedimentology, tectonics, and mineralogical characteristics of the Alcotas Formation have been studied in detail (López-Gómez and Arche, 1993; Alonso-Azcárate et al., 1997; Arche and López-Gómez, 1999, 2005; Benito et al., 2005; De la Horra et al., 2008; Vargas et al., 2009). It consists of red to dark brown mudstone and siltstone with local lenticular sandstone and conglomerate bodies and has been dated as "Thuringian age" (sensu Visscher, 1971) (=Zechstein) in the study area. The "Thuringian age" fits well with the Tatarian Stage of the Upper Permian of the Russian Platform, although a Middle Permian age cannot be ruled out for part of the Formation (De la Hor ra et al., 2008).

The total thickness of Alcotas Formation is up to $185 \mathrm{~m}$ in the study area being subdivided into three parts (Lower, Middle and Upper) based on the presence and type of paleosols, coal horizons, palynological assemblages, macrofloras, mineralogy, and sedimentary structures (Fig. 3). The boundaries between these three parts are related to important palaeoenvironmental and palaeogeographical changes (Arche and López-Gómez, 2005; Benito et al., 2005; López-Gómez et al., 2005; De la Horra et al., 2008).

The Lower Part (LP) represents more than half of the formation and includes carbonate paleosols (Fig. 3). It is mainly composed of pale red mudstones and siltstones with intercalated medium to coarse-grained sandstone bodies. This part is interpreted as a sandy-gravelly braided fluvial system containing a wide fine-grained floodplain with high avulsion rate (Arche and López-Gómez, 1999, 2005).

The Middle Part (MP) represents an abrupt change in lithof acieswith respect to the underlying $L P$ sedimentary rocks. It mainly consists of sandstone bodies, amalgamated or separated by massive siltstonemudstone bodies. These bodies are interpreted as meandering and braided fluvial systems that crossed wide alluvial plains (López-Gómez and Arche, 1993; Arche and López-Gómez, 2005). Weakly developed paleosolswith no carbonate content have been identified in this interval (De la Horra, 2008).

The Upper Part (UP) consists of fine to medium-grained sandstone bodies ( $\mathrm{cm}$ - to $\mathrm{m}$-scale) separated by mudstone-siltstone beds. Very few paleosols have been identified in this interval and none of them contain carbonate. The sediments of this Upper Part are related to distal, very lowenergy sandy braided riversystems with high avulsion rate and marked seasonality (Arche and López-Gómez, 2005).

\section{The carbonate paleosols of the Alcotas Formation}

Carbonate paleosols developed within the Lower Part of the Alcotas Formation (Figs. 3, 4A-D) have been studied in detail in three stratigraphic sections (Landete, Talayuelas and Henarejos; Figs. 1, 3) where they are most abundant and best preserved (Benito et al., 2005; De la Horra et al., 2008).

Parent materials of the paleosols are dominantly siltstone to very fine sandstone facies of overbank deposits of floodplains, although some paleosols developed on top of thick sandstone beds. The petrographic study of the sandstones shows a predominance of subarkoses, with minor presence of quartzarenites and arkoses and abundant mica fragments (muscovite and/or biotite). The mineralogical composition of the fine-grained sediments includes clay minerals (illite and some kaolinite), quartz, and varying proportions of feldspar and hematite (De la Horra et al., 2008). The bulk mineralogical composition of paleosols, as determined by XRD, include dolomite, magnesite, Fe-magnesite, quartz and phyillosilicates (mainly illite and kaolinite), as the most abundant minerals, and traces of feldspar and calcite.

Carbonate paleosols have been assigned to Calcisols (Mack et al., 1993) developed under semiarid conditions (De la Horra et al., 2008). According to these authors, carbonate paleosols of the Lower Part of Alcotas Formation range from weakly developed, consisting of small carbonate nodules and veinlets, to moderately developed paleosols, which include in their profile horizons of calcareous nodules. The more developed paleosols consist of an indurated and cemented petrocalcic horizon developed in some stable and innermost areas, far away from the borders of the basin (De la Horra et al., 2008).

\subsection{Petrographical and geochemical observations}

The mineralogy and texture of the original carbonate are not preserved in most of the paleosols because they are replaced by coarse crystals of dolomite and/or magnesite. The carbonate precursor of some paleosols is preserved only in the Talayuelas section, and it is constituted by non-ferroan and dark red luminescent dolomicrite (Benito et al., 2005).

\subsubsection{Dolomite}

In the studied sections the carbonate precursor, which precipitated during the development of paleosols (as nodules, veinlets, cracks and root casts, Fig. 4A-D), is replaced by a mosaic of coarse dolomite crystals displaying bright and intense reddish luminescence (Fig. 5). In the Landete and Talayuelas sections dolomite crystals are generally euhedral and rhombohedral in habit, with diameters ranging from 100 to $500 \mu \mathrm{m}$, and display "straight" extinction (Fig. 5A-D); in the Henarejos section, however, dolomite crystals are larger, generally ranging from several hundreds of microns to more than $1 \mathrm{~mm}$, subeuhedral to anhedral and frequently exhibit saddle habit with curved faces and sweeping extinction (Fig. 5E-F).

Occasionally, in the three studied sections dolomite occurs as a cement, filling larger cracks created during paleosol development (Fig. 5G-H). In these cases, dolomite crystals display zoning with cloudy dolomite in the core and limpid dolomite in the outer part. Cloudy dolomite displays reddish luminescence (RL), and limpid dolomite displays red luminescence first and subsequently dark dull brownish to non-luminescence (Fig. 5G-H). 

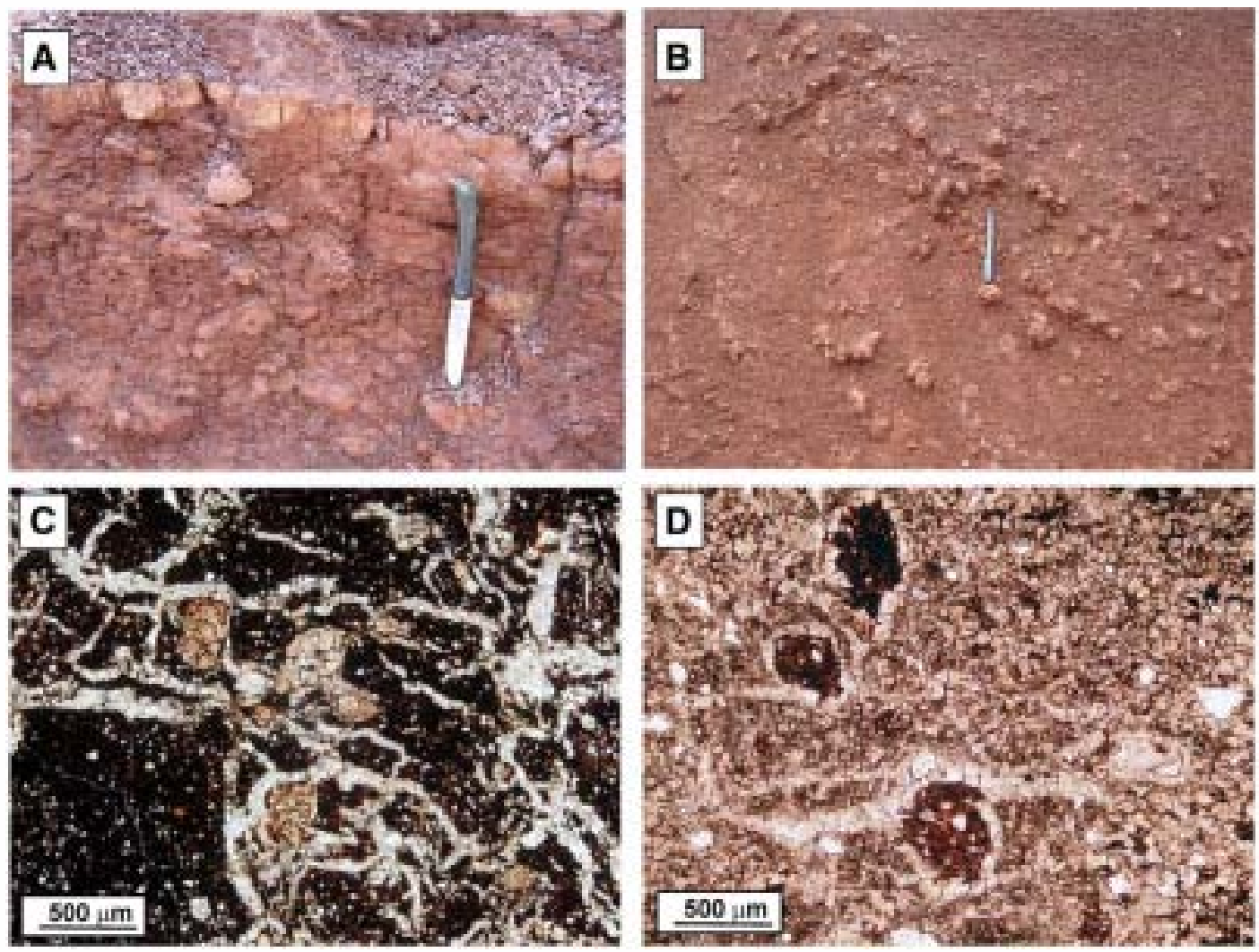

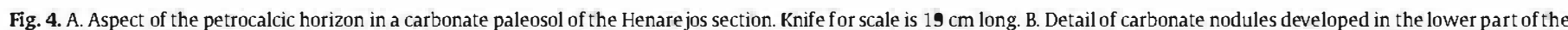

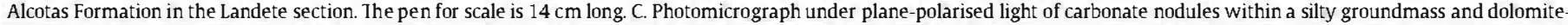

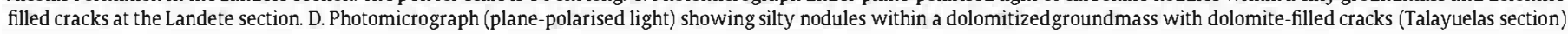

analyses were performed yielding values between -9.2 and $-11.2 \%$ for oxygen and between -7.0 and $-7.1 \%$ for carbon and ${ }^{87} \mathrm{Sr} /{ }^{\beta 6} \mathrm{Sr}$ ratio of 0.71829 (Fig. 8).

\subsubsection{Magnesite}

Dolomite is partially or totally replaced by magnesite in some samples of the Landete and Talayuelas sections; however, no magnesite has been observed in the Henarejos section. Magnesite is difficult to distinguish from dolomite if CL microscopy or microprobe analyses are not used (Fig. 6C-F).

In both sections magnesite is composed of non- to dark dull luminescence subeuhedral to anhedral crystals up to $500 \mu \mathrm{m}$ wide (Fig. 6C-H), although occasionally magnesite crystals are larger than $1 \mathrm{~mm}$. In the Landete section magnesite is more abundant upwards in the stratigraphic section where some paleosols are completely replaced by this mineral. In contrast, in the lower part of the stratigraphic section magnesite is scattered or absent and only replaces dolomite partially. In the Talayuelas section, however, ferroan magnesite (breunnerite) has been observed only in the lower part of the section where it replaces completely carbonate precursors. In both sections magnesite crystals are aff ected by stylolites, indicating that magnesite precipitated prior to chemical compaction (Fig. 6H).

Magnesite in the Landete section has high Fe content (mean value $6.31 \mathrm{FeCO}_{3} \mathrm{~mol} \%$ ), moderate $\mathrm{Mn}$ content (mean value: $0.85 \mathrm{MnCO}_{3}$ mol\%), andlow to very low $\mathrm{Ca}, \mathrm{Na}$, and Srcontents (Table 1 ; Fig. 9). In the Talayuelas section magnesite has low to very low $\mathrm{Ca}, \mathrm{Na}$, and $\mathrm{Sr}$ contents, moderate to high $\mathrm{Mn}$ content (mean value: $1.43 \mathrm{MnCO}_{3} \mathrm{~mol} \%$ ) and much higher $\mathrm{Fe}$ content (mean value: $34.3 \mathrm{FeCO}_{3} \mathrm{~mol} \%$ ) than in Landete (Fig. 9). Moreover, in the latter locality magnesite crystals are occasionally zoned (Fig. 6G), with the outer zones (OP) containing slightly higher amounts of Fe and Mn than the core (IP; Fig. 9).
Carbon and oxygen isotopes are also different in the two sections. In the Landete section, the oxygen isotope composition of magnesite ranges from -5.5 to $-6.9 \%$ and the carbon isotope compositions range from -4.6 to $-7.9 \%$ (Table 1 ; Fig. $8 A$ ). In the Talayuelas section, oxygen isotopic composition yields values between -7.1 and $-8.8 \%$ and carbon between -5.7 and $-6.7 \%$. The ${ }^{87} \mathrm{Sr} /{ }^{86} \mathrm{Sr}$ ratios of magnesites are similar in the two sections yielding values between 0.71258 and 0.72508 in Iandete, with the higher values corresponding to magnesite replacing fine-grained sandstones. The only measurement of ${ }^{87} \mathrm{Sr} /{ }^{86} \mathrm{Sr}$ ratio in magnesite of Talayuelas section is 0.72070 (Table 1 ; Fig. 8B).

\section{Discussion}

\subsection{Dolomite}

The similar petrographic, elemental geochemistry and Sr isotopes of dolomite in the three studied localities suggest that it precipitated from similar fluids and under similar diagenetic environmental conditions. As previously pointed out, micas are deformed by dolomite crystals indicating that dolomite precipitated prior to or during the first stages of mechanical compaction; moreover, the relatively high Mn content and low Fe content of RL dolomite suggest that it precipitated under suboxic conditions. Thus, probably RL dolomite precipitated during shallow burial diagenesis. During progressive burial fluids became more reduced and ferroan DL dolomite precipitated postdating RL dolomite (Fig. 5G-H).

The carbon isotopic values of RL dolomite are negative in the three studied sections (Fig. 8A). These values probably reflectthe original light ${ }^{13} \mathrm{C}$ composition of the carbonate precursor precipitated during paleosol development, as the ${ }^{13} \mathrm{C}$ values of replacive carbonates exhibit 

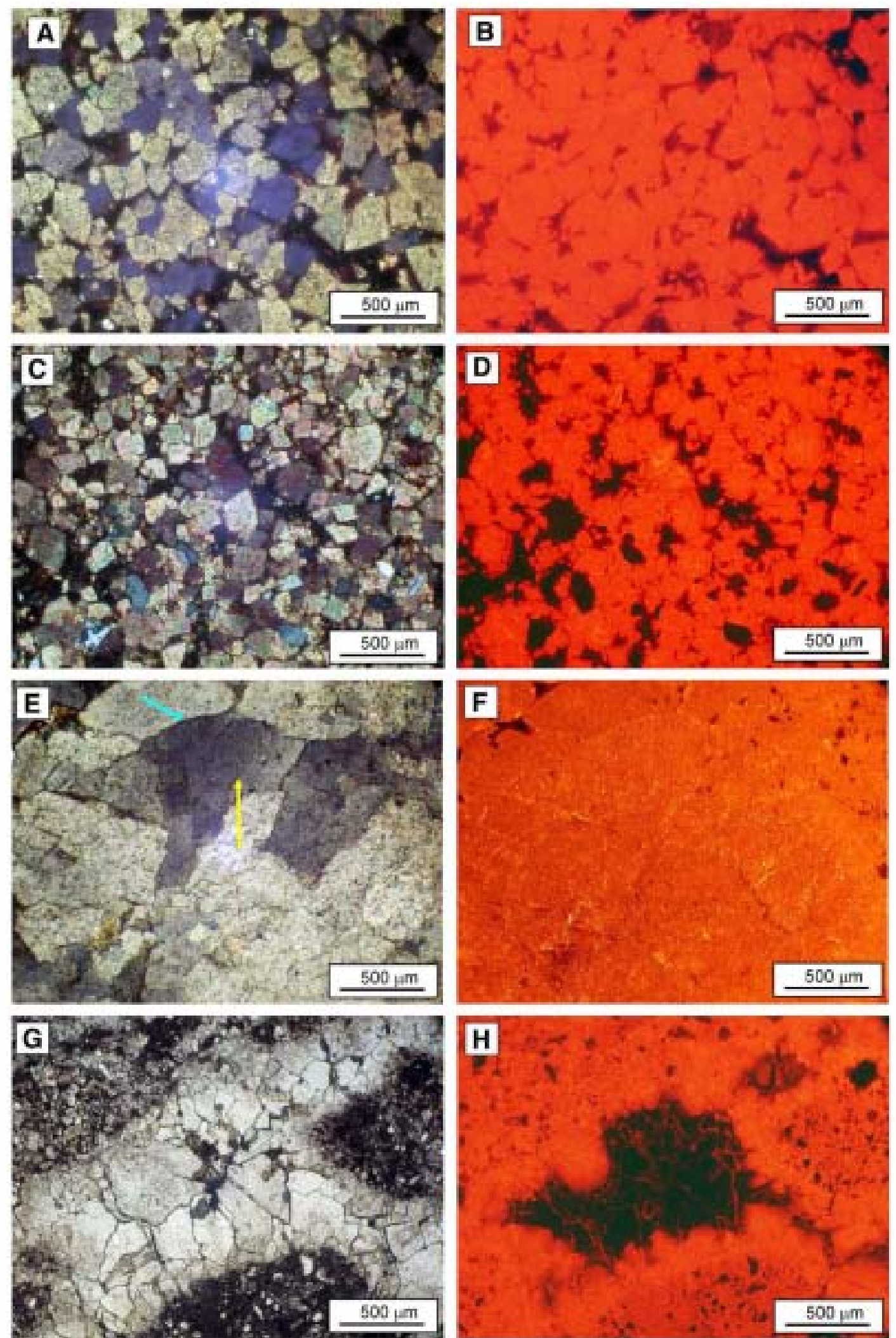

Fig. 5. A. Mosaic of euhedral to subeuhedral, rhombohedral dolomite crystals under polarised light. Landete section. B. Same image than $A$ under CL Note the intense reddish luminescence (RL) of dolomite. C. Mosaic of euhedral to subeuhedral rhombohedral dolomite crystals under polarised light. Talayuelas section. D. Same image than C under CL. Note the similarities with dolomite precipitated in the Landete section. E. Sample from Henare jos section showing coarsenon-planar dolomite under polarised light. Note the curved faces (blue arrow) and sweeping extinction (yellow arrow) of the crystals, typical of saddle habit. F. Same image than E under CL. G. Dolomite crystals filling a pedogenic crack (transmitted light). Talayuelas section. H. Same image than $\mathrm{G}$ under $\mathrm{CL}$. Note the intense reddish luminescence of the first generation of dolomite. This is followed by dark dull luminescent dolomite, which completely fills porosity. 

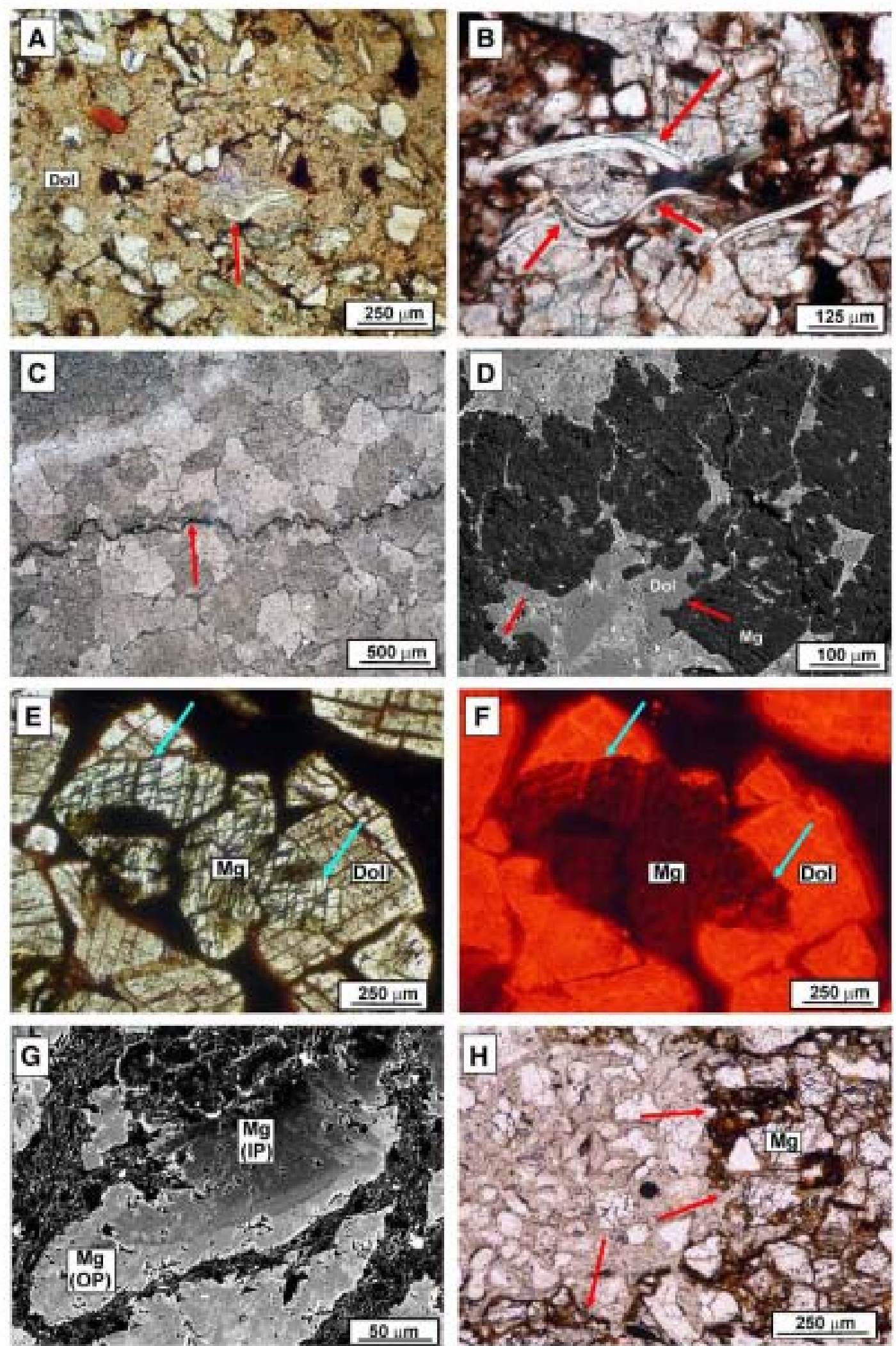

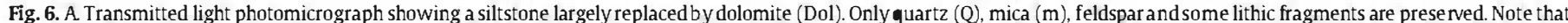

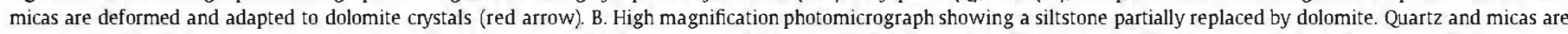

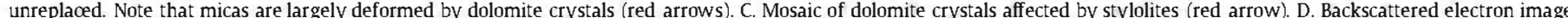

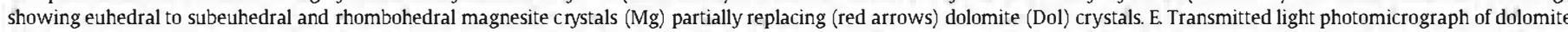

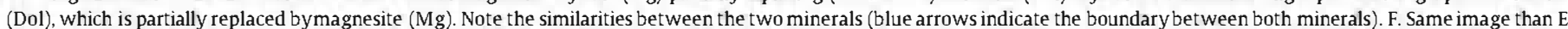

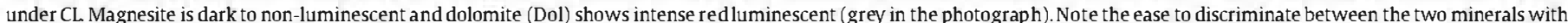

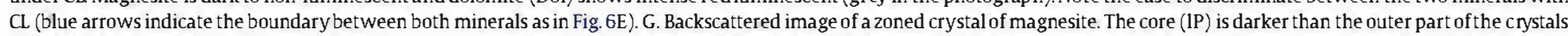

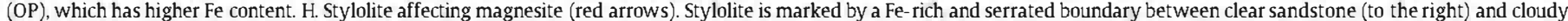
sandstone (to the left). 

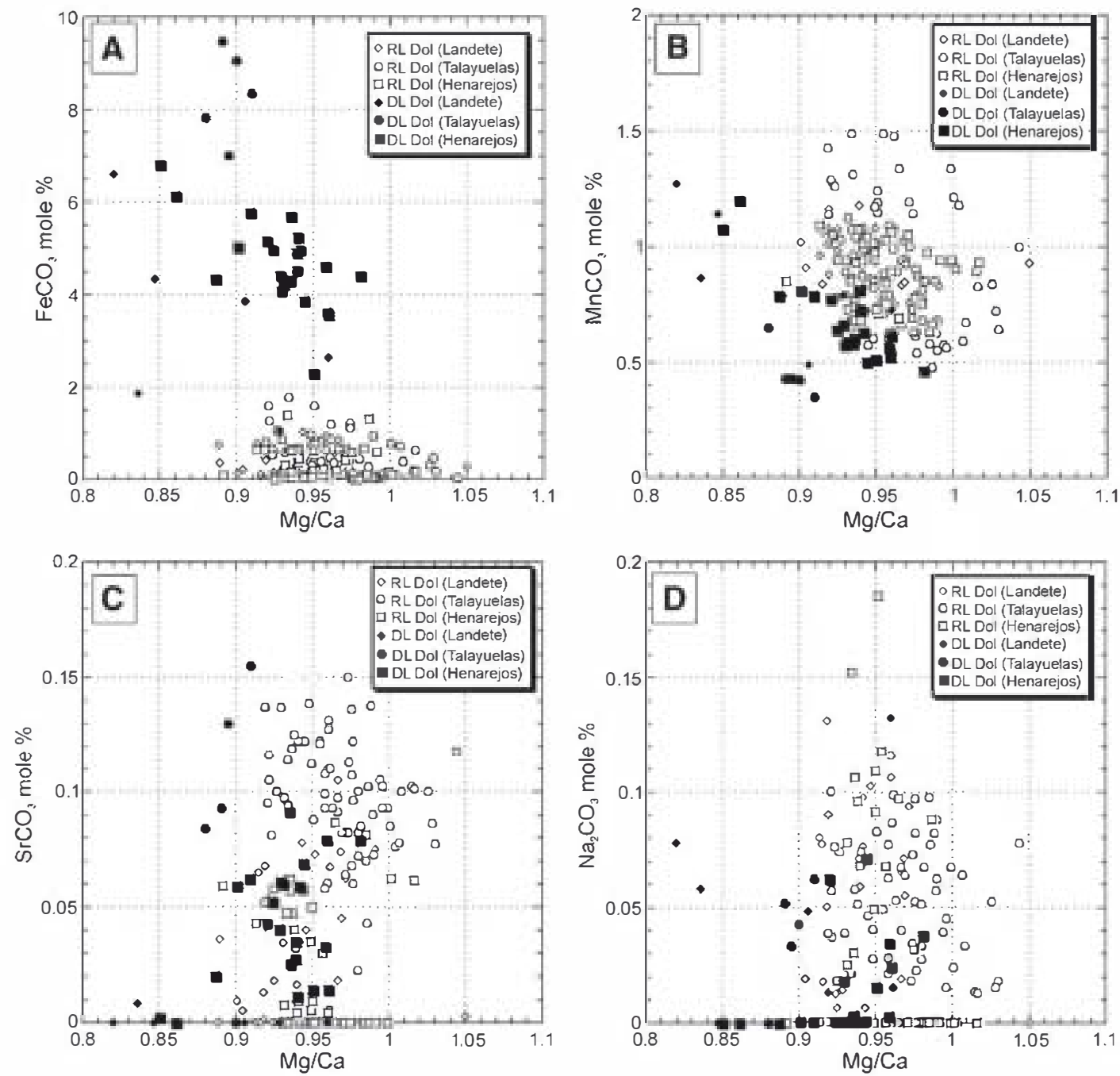

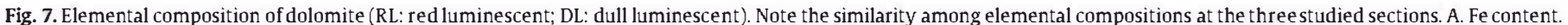
B. Mn content. C. Sr content; and D. Na content.

the isotopic composition of carbonate host rock even at low rock/water interaction rates (Lohmann, 1987).

The $\delta^{18} \mathrm{O}$ values of dolomite, however, are different in each locality (Fig. 8A). Oxygen isotopic composition of carbonates depends on the isotopic composition of the fluid and the temperature of precipitation (e.g. Hoefs, 2004), thus the different $\delta^{18} \mathrm{O}$ values of dolomite may reflect either a change in the isotopic composition of the fluid, a change in the temperature of precipitation or a combination of both. The petrographic features and elemental geochemistry of dolomite in the three sections are very similar, thus it is unlikely that the chemistry of fluids from which dolomite precipitated was different. It could be argued that dolomite precipitated from the mixing of two fluids with different oxygen isotopic composition if there were variations in the mixing ratios from site to site. However, there is a relatively small range of fluid chemical compositions permissive of mixing-zone dolomitisation (e.g. Hardie, 1987), and thus it is unlikely that different mixing ratios of two fluids at the three sections could precipitate dolomite which, in turn, has almost identical petrography and elemental chemistry. Moreover, if mixing had have occurred, one would also expect to see far greater variation in $\delta^{18} \mathrm{O}$ compositions of dolomite within each locality, not only among the three sites (Lohmann, 1987).

Another possibility is that the variation in the oxygen isotopic composition of dolomite at the three sections likely reflects changes in the temperature of precipitation rather than a change in the fluid chemistry. This would be in agreement with petrographic and geochemical data. According to Gregg and Sibley (1984), mosaics of idiotopic crystals (as those observed in the Landete and Talayuelas sections, Fig. 5A-D) indicate growth temperatures below $50^{\circ} \mathrm{C}$, while those with non-planar boundaries (as those observed in the Henare jos section, Figs. SE-F; 6C) result from elevated temperatures greater than $50{ }^{\circ} \mathrm{C}$. Moreover, dolomite in the Henarejos section displays a saddle crystal habit, which forms at temperatures ranging from 60 to $160^{\circ} \mathrm{C}$ (Radke and Mathis, 1980; Spötl and Pitman, 1998) and it is considered as a useful geothermometer, indicating minimum burial temperatures of 60 to $150^{\circ} \mathrm{C}$ (Warren, 2000). Thus, the very similar perographic and geochemical data of dolomite in the three studied sections, along with the combined occurrence of saddle dolomite in the Henare jos section and the lower $\delta^{18} \mathrm{O}$ values of dolomite in this site compared to those obtained at Landete and Talayuelas, reinforce the hypothesis that dolomite in the three sections precipitated from similar fluids but at different temperatures.

If it is assumed that dolomite precipitated from a fluid with similar oxygen isotopic composition at the three localities, as suggested from their petrographic and elemental geochemical similarities, then it is possible to calculate the differences in the temperature of dolomite precipitation among the three sites. At this point it is important to note that burial history at the three localities was very similar (Fig. 2, 3; Vargas et al, 2009). Plotting the $\delta^{18} \mathrm{O}$ values of dolomite (in VPDB) versus temperature for several $\delta^{18} \mathrm{O}$ values of the water (in VSMOW), derived from the fractionation equation $10^{3} \ln \alpha_{\mathrm{dol}-\mathrm{w}}=2.78^{*} 10^{6} \mathrm{~T}^{-2}$ 
Table 1

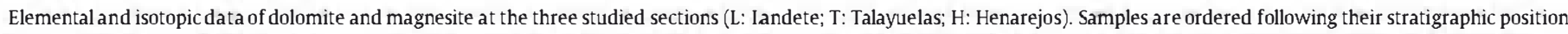

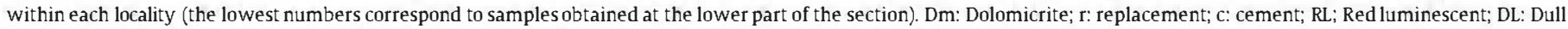
luminescent; NL: Non- to dark dull luminescenœ; m.v.: mean values. Elemental compositions are expressed in $\mathrm{MeCO}_{3}$ mol\%.

\begin{tabular}{|c|c|c|c|c|c|c|c|c|c|c|}
\hline \multirow[t]{2}{*}{ Locality } & \multirow[t]{2}{*}{ Sample } & \multirow{2}{*}{$\frac{6^{18} 0}{V P D B}$} & \multirow{2}{*}{$\frac{\delta^{13} \mathrm{C}}{\text { VPDB }}$} & \multirow[t]{2}{*}{${ }^{87} \mathrm{Sr}^{/ 86} \mathrm{Sr}$} & \multirow{2}{*}{$\begin{array}{l}\mathrm{MgCO}_{3} \\
\text { (m.v.) }\end{array}$} & \multirow{2}{*}{$\begin{array}{l}\mathrm{CaCO}_{3} \\
\text { (m.v.) }\end{array}$} & \multirow{2}{*}{$\begin{array}{l}\mathrm{FeCO}_{3} \\
\text { (m.v.) }\end{array}$} & \multirow{2}{*}{$\begin{array}{l}\mathrm{MnCO}_{3} \\
\text { (m.v.) }\end{array}$} & \multirow{2}{*}{$\begin{array}{l}\mathrm{SrCO}_{3} \\
\text { (m.v.) }\end{array}$} & \multirow{2}{*}{$\begin{array}{l}\mathrm{Na}_{2} \mathrm{CO} \\
\text { (m.v.) }\end{array}$} \\
\hline & & & & & & & & & & \\
\hline \multicolumn{11}{|l|}{ Dolomite } \\
\hline \multirow[t]{13}{*}{ Landete } & L-1 r (RL) & -6.60 & -3.93 & & 47.42 & 51.06 & 0.40 & 1.04 & 0.011 & 0.066 \\
\hline & $\mathrm{L}-2 \mathrm{r}(\mathrm{RL})$ & -6.12 & -4.64 & 0.714062 & 48.46 & 50.10 & 0.44 & 0.87 & 0.002 & 0.121 \\
\hline & $\mathrm{L}-3 \mathrm{r}(\mathrm{RL})$ & -6.63 & -4.05 & & 47.71 & 51.13 & 0.28 & 0.83 & 0.017 & 0.026 \\
\hline & $\mathrm{L}-4 \mathrm{r}(\mathrm{RL})$ & -6.78 & -3.27 & & 48.50 & 50.00 & 0.52 & 0.84 & 0.070 & 0.063 \\
\hline & $\mathrm{L}-4 \mathrm{c}(\mathrm{RL})$ & -6.84 & -3.58 & & 48.13 & 50.39 & 0.65 & 0.79 & 0.024 & 0.018 \\
\hline & L-5 r (RL) & -6.77 & -3.94 & 0.720004 & & & & & & \\
\hline & L-6 r (RL) & -6.93 & -4.60 & 0.716193 & 48.52 & 49.91 & 0.50 & 0.96 & 0.003 & 0.115 \\
\hline & L-7 r (RL) & -6.54 & -3.90 & 0.714107 & 48.20 & 50.30 & 0.52 & 0.87 & 0.004 & 0.105 \\
\hline & $\mathrm{L}-8 \mathrm{r}(\mathrm{RL})$ & -6.95 & -4.04 & & & & & & & \\
\hline & $\mathrm{L}-8 \mathrm{c}(\mathrm{RL})$ & -7.01 & -4.56 & & 46.92 & 51.52 & 0.48 & 0.99 & 0.009 & 0.075 \\
\hline & L-8 c (DL) & & & & 43.64 & 49.92 & 5.36 & 1.06 & 0.009 & 0.008 \\
\hline & L-9 r (RL) & -6.30 & -3.58 & & 47.47 & 51.34 & 0.13 & 1.03 & 0.008 & 0.028 \\
\hline & $\mathrm{L}-10 \mathrm{r}(\mathrm{RL})$ & -6.57 & -3.98 & & 48.02 & 50.44 & 0.48 & 0.99 & 0.054 & 0.024 \\
\hline \multirow[t]{9}{*}{ Talayuelas } & $\mathrm{T}-3 \mathrm{r}(\mathrm{RL})$ & -6.12 & -4.17 & 0.722134 & 48.62 & 49.86 & 0.62 & 0.80 & 0.005 & 0.089 \\
\hline & $\mathrm{T}-2 \mathrm{r}(\mathrm{RL})$ & -5.39 & -5.55 & & 47.72 & 50.53 & 0.72 & 0.94 & 0.004 & 0.098 \\
\hline & $\mathrm{T}-5 \mathrm{r}(\mathrm{RL})$ & -5.44 & -6.80 & & 49.00 & 49.58 & 0.49 & 0.77 & 0.090 & 0.077 \\
\hline & $\mathrm{T}-5 \mathrm{c}(\mathrm{RL})$ & -5.46 & -6.52 & 0.715765 & 48.27 & 50.29 & 0.38 & 0.89 & 0.087 & 0.077 \\
\hline & $\mathrm{T}-5 \mathrm{c}(\mathrm{DL})$ & & & & 42.99 & 48.07 & 8.34 & 0.48 & 0.093 & 0.038 \\
\hline & T-6 Dm (RL) & -4.79 & -5.54 & & 48.06 & 50.16 & 0.54 & 1.10 & 0.101 & 0.038 \\
\hline & T-6 r (RL) & -5.07 & -5.73 & 0.713908 & & & & & & \\
\hline & $\mathrm{T}-7 \mathrm{r}(\mathrm{RL})$ & -5.38 & -6.74 & 0.715282 & 47.94 & 50.64 & 0.41 & 1.01 & 0.002 & 0.001 \\
\hline & $\mathrm{T}-8 \mathrm{r}(\mathrm{RL})$ & -6.12 & -3.92 & & 48.41 & 50.48 & 0.18 & 0.78 & 0.098 & 0.048 \\
\hline \multirow[t]{18}{*}{ Henare jos } & $\mathrm{H}-1 \mathrm{r}(\mathrm{RL})$ & -8.42 & -8.76 & & 48.43 & 50.26 & 0.32 & 0.98 & 0.005 & 0.002 \\
\hline & $\mathrm{H}-2 \mathrm{r}(\mathrm{RL})$ & -8.22 & -7.97 & 0.716110 & & & & & & \\
\hline & $\mathrm{H}-3 \mathrm{r}(\mathrm{RL})$ & -8.03 & -7.74 & & & & & & & \\
\hline & $\mathrm{H}-4 \mathrm{r}(\mathrm{RL})$ & -7.89 & -8.18 & 0.717549 & 48.00 & 50.67 & 0.38 & 0.82 & 0.023 & 0.107 \\
\hline & $\mathrm{H}-4 \mathrm{c}(\mathrm{RL})$ & -7.88 & -8.11 & 0.719730 & 48.60 & 50.27 & 0.31 & 0.74 & 0.027 & 0.053 \\
\hline & $\mathrm{H}-5 \mathrm{r}(\mathrm{RL})$ & -8.22 & -7.92 & & 47.76 & 50.78 & 0.40 & 0.97 & 0.051 & 0.044 \\
\hline & $\mathrm{H}-5 \mathrm{c}(\mathrm{DL})$ & -7.06 & -11.08 & 0.718286 & 45.56 & 49.16 & 4.48 & 0.73 & 0.064 & 0.014 \\
\hline & $\mathrm{H}-6 \mathrm{r}(\mathrm{RL})$ & -7.50 & -8.52 & 0.718273 & & & & & & \\
\hline & $\mathrm{H}-7 \mathrm{r}(\mathrm{RL})$ & -6.95 & -8.30 & & 47.66 & 51.06 & 0.38 & 0.83 & 0.045 & 0.025 \\
\hline & $\mathrm{H}-7 \mathrm{c}(\mathrm{DL})$ & -7.01 & -9.16 & & 45.94 & 48.56 & 4.79 & 0.66 & 0.036 & 0.014 \\
\hline & $\mathrm{H}-8 \mathrm{r}(\mathrm{RL})$ & -7.54 & -8.53 & & & & & & & \\
\hline & $\mathrm{H}-9 \mathrm{r}(\mathrm{RL})$ & -7.17 & -8.03 & 0.719200 & 47.62 & 50.94 & 0.60 & 0.76 & 0.062 & 0.015 \\
\hline & $\mathrm{H}-10 \mathrm{r}(\mathrm{RL})$ & -7.99 & -8.17 & & & & & & & \\
\hline & $\mathrm{H}-11 \mathrm{r}(\mathrm{RL})$ & -7.16 & -8.08 & & 49.24 & 49.30 & 0.70 & 0.66 & 0.011 & 0.088 \\
\hline & $\mathrm{H}-11 \mathrm{c}(\mathrm{RL})$ & -7.24 & -8.43 & & 47.77 & 51.11 & 0.21 & 0.73 & 0.020 & 0.152 \\
\hline & $\mathrm{H}-12 \mathrm{r}(\mathrm{RL})$ & -7.23 & -7.84 & & 47.95 & 50.35 & 0.77 & 0.72 & 0.022 & 0.185 \\
\hline & $\mathrm{H}-13 \mathrm{r}(\mathrm{RL})$ & -7.07 & -8.10 & 0.717094 & 47.74 & 50.76 & 0.42 & 0.93 & 0.047 & 0.106 \\
\hline & $\mathrm{H}-13 \mathrm{c}(\mathrm{RL})$ & -6.85 & -8.68 & & 48.15 & 50.74 & 0.06 & 0.97 & 0.035 & 0.049 \\
\hline \multicolumn{11}{|l|}{ Magnesite } \\
\hline \multirow[t]{7}{*}{ Landete } & $\mathrm{L}-1 \mathrm{r}(\mathrm{NL})$ & -6.54 & -6.90 & & 90.94 & 0.16 & 7.93 & 0.97 & 0.001 & 0.002 \\
\hline & $\mathrm{L}-4 \mathrm{r}(\mathrm{NL})$ & -4.65 & -5.46 & & 94.30 & 0.44 & 4.55 & 0.68 & 0.010 & 0.025 \\
\hline & L-9 r (NL) & -6.42 & -6.37 & & 92.01 & 0.13 & 6.94 & 0.90 & 0.009 & 0.019 \\
\hline & L-11r (NL) & -5.51 & -6.67 & 0.725078 & 90.10 & 0.53 & 8.40 & 0.96 & 0.005 & 0.008 \\
\hline & $\mathrm{L}-12$ r (NL) & -6.77 & -6.41 & 0.714976 & 89.21 & 3.20 & 6.71 & 0.80 & 0.002 & 0.073 \\
\hline & $\mathrm{L}-13 \mathrm{r}(\mathrm{NL})$ & -6.71 & -6.79 & 0.712581 & 90.07 & 3.55 & 5.55 & 0.80 & 0.001 & 0.039 \\
\hline & $\mathrm{L}-14 \mathrm{r}(\mathrm{NL})$ & -7.93 & -5.80 & 0.71452 & 94.97 & 0.41 & 3.87 & 0.68 & 0.018 & 0.050 \\
\hline Talayuelas & $\mathrm{T}-1 \mathrm{r}(\mathrm{NL})$ & -5.75 & -8.76 & 0.720696 & 61.36 & 1.10 & 36.02 & 1.52 & 0.009 & 0.001 \\
\hline & $\mathrm{T}-3 \mathrm{r}(\mathrm{NL})$ & -5.69 & -7.62 & & 63.90 & 0.99 & 33.90 & 1.16 & 0.050 & 0.003 \\
\hline & $\mathrm{T}-4 \mathrm{r}(\mathrm{NL})$ & -6.67 & -7.07 & & 67.87 & 0.89 & 29.67 & 1.48 & 0.076 & 0.019 \\
\hline
\end{tabular}

+0.11 (Fritz and Smith, 1970), the range of possible temperatures of precipitation of RI dolomite among the three localities can be estimated (Fig. 10A). Based upon the aforementioned assumptions, the temperatures estimated using this formula indicate that the highest precipitation temperature would have been reached at Henare jos followed by Talayuelas and finally by Landete, whether or not one considers the mean $\delta^{18} \mathrm{O}$ values or the whole range of $\delta^{18} \mathrm{O}$ values for RL dolomites observed in each section (Fig. 10A).

As mentioned above, we have assumed a minimum temperature of $60{ }^{\circ} \mathrm{C}$ for saddle dolomite precipitation in the Henare jos section, although it is important to note that the overall implications of this study would not significantly change if slightly higher or lower temperatures than $60^{\circ} \mathrm{C}$ are chosen (Fig. 10A). Considering this temperature as a starting point and assuming a similar fluid composition at the three localities, then the oxygen isotopic composition of the water from which RL dolomite precipitated could be constrained (Fig. 10A). Thus, in order to precipitate RI. dolomite at Henare jos at $60{ }^{\circ} \mathrm{C}$ and at Talayuelas and Landete at lower temperature (specifically at $16{ }^{\circ} \mathrm{C}$ and $25{ }^{\circ} \mathrm{C}$ lower than in Henarejos, respectively, Fig. $10 \mathrm{~A}$ ), the $\delta^{18} \mathrm{O}$ of the water from which dolomites crystallised ranged between -0.3 and $-2.9 \%$ VSMOW (Fig, 10A). These $\delta^{18} \mathrm{O}_{\text {water }}$ values would not change significantly if slightly higher or lower temperatures than $60^{\circ} \mathrm{C}$ were assumed for saddle dolomite precipitation at Henare jos (Fig. 10A).

Dull luminescent (DL) ferroan dolomite precipitated during progressive burial at the three localities (Fig. 5G-H), and therefore probably precipitated at higher temperatures than RI dolomite. This is in 

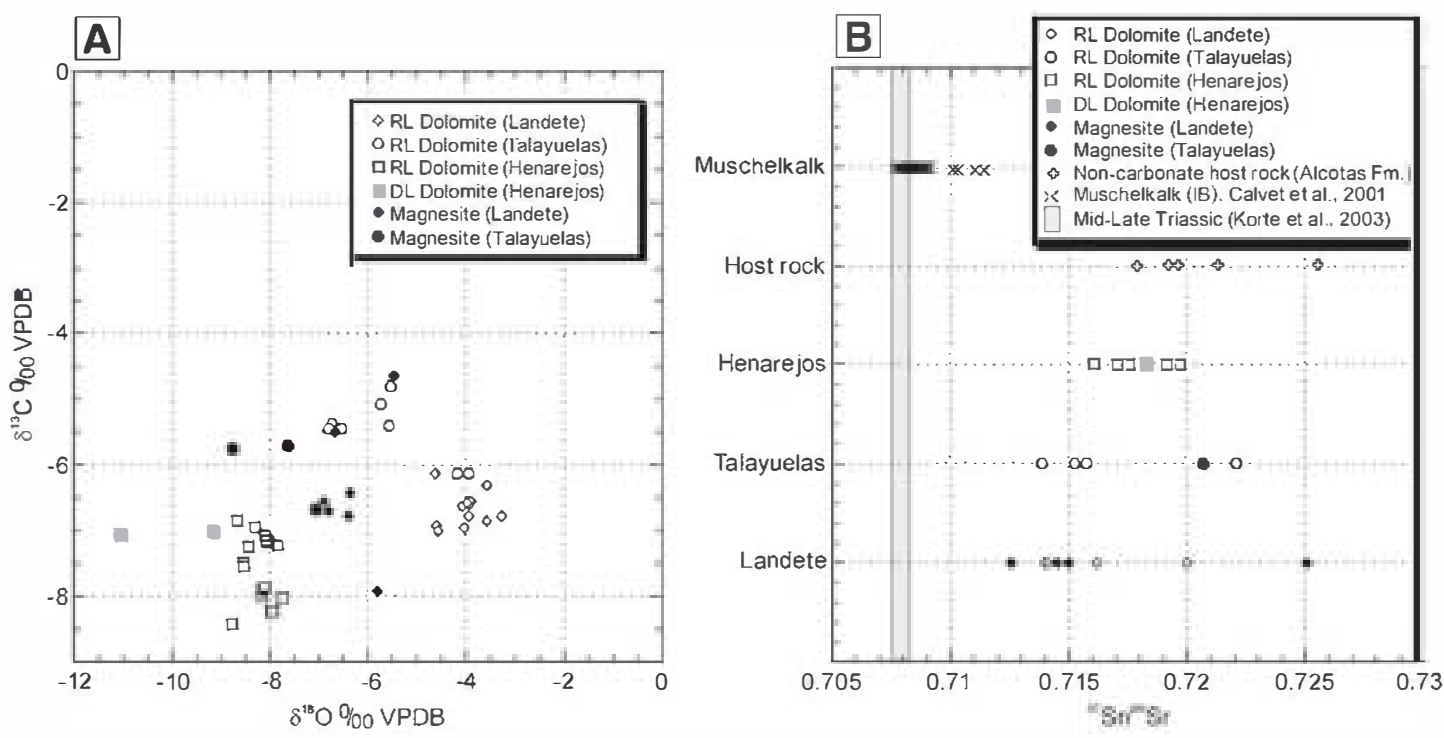

Fig. 8. A. Carbon and oxygen stable isotope composition of dolomite (RL: red luminescent; DL: dull luminescent) and magnesite at the studied sections. B. ${ }^{87} \mathrm{Sr} /{ }^{6} \mathrm{Sr}$ ratios of dolomite and magnesite in the three studied sections. The Sr isotopic composition of lutites and siltstones of Alcotas Formation, Muschelkalkdolomites of the Iberian Basin (based on Calvet et aL, 2001), and the mean values for mid to upper Triassic marine carbonates (Korte et al., 2003) are also plotted.
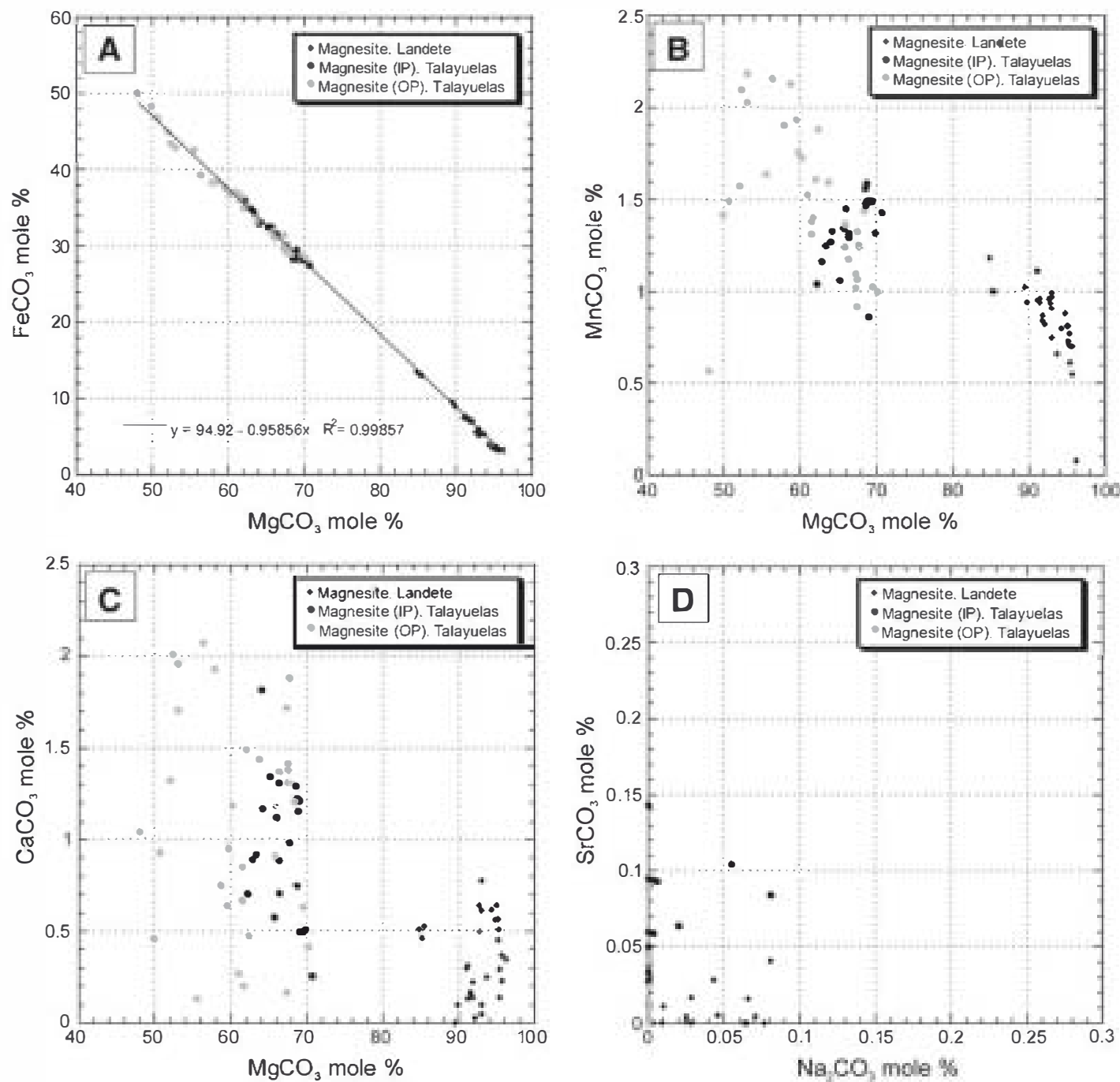

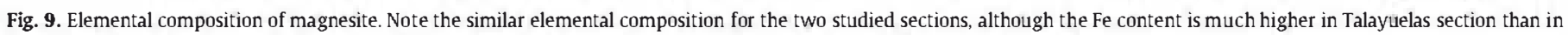
Landete section. A. Fe content. B. Mn content. C. Ca content; D. Sr versus Na content. IP: Inner part, and OP: Outer part. 

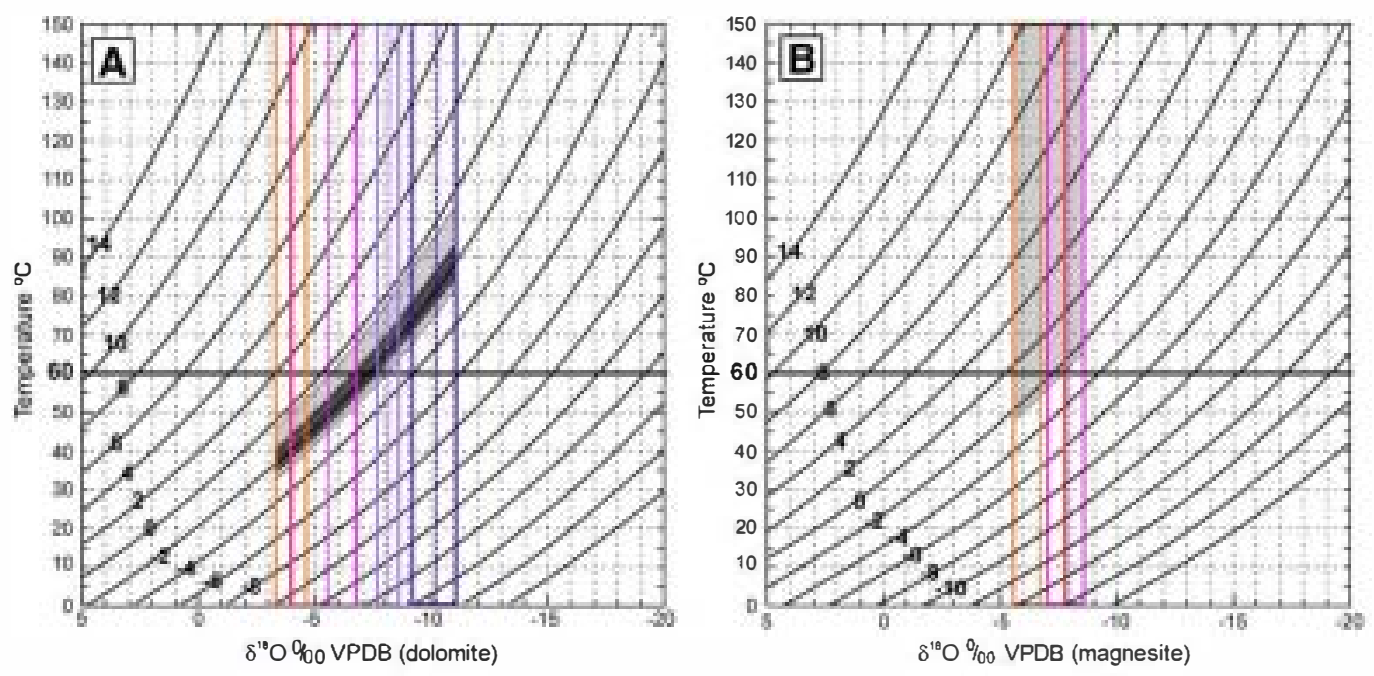

Landete (RL dolomite and magnesite)
Talayuelas (RL dolomite and magnesite)

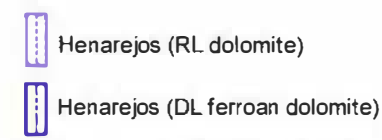

"For each location, the continuous lines represent the range of $\delta^{18} \mathrm{O}$ values of dolomite or magnesite.

The dotted lines correspond to the mean $\delta^{16} \mathrm{O}$ values.

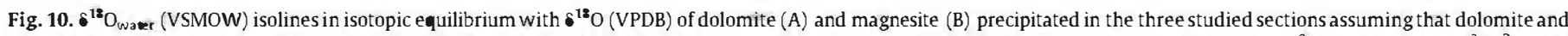

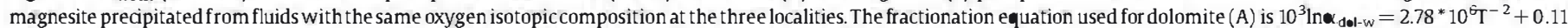

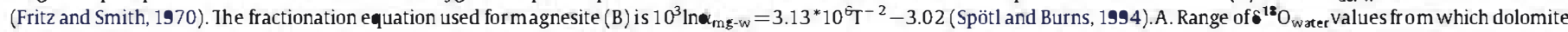

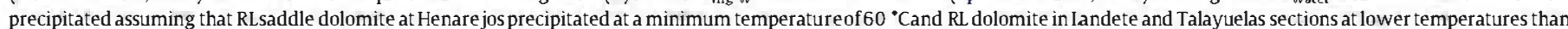

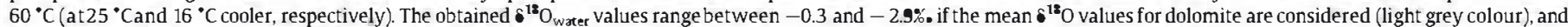

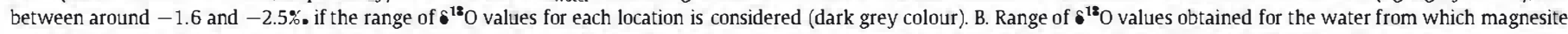

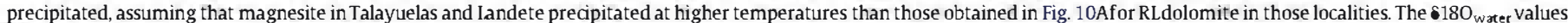
obtained are heavier than $-2.5 \%$ (grey colour).

agreement with the isotopic data from the Henare jos section, if it is considered thatthe $~^{18} \mathrm{O}$ of the water did not significantly change during progressive precipitation (Fig. 10A). Thus, assuming that RL dolomite at Henare jos precipitated at least at $60^{\circ} \mathrm{C}$, the increment of temperature for DL dolomite precipitation at Henare jos would have been of $\approx 20^{\circ} \mathrm{C}$ hotter (Fig. 10A).

\subsection{Magnesite}

Magnesite has been observed only at Talayuelas and Iandete sections. It replaces dolomite (Fig. 6D-F) and precipitated during progressive burial but before chemical compaction as revealed by stylolites affecting magnesite crystals (Fig. 6H). In these two localities magnesite has similar perographic features and similar $\mathrm{Sr}$ isotope ratios, although Fe content is much higher in the Talayuelas than in the Landete stratigraphic section (Fig. 9). The similarity between magnesites from both localities suggests that they could have precipitated from similar fluids under similar diagenetic environmental conditions. Considering the complete solid solution between magnesite and siderite (e.g. Changet al., 1996), the differences in the Fe content between both sections could be due to local compositional differences in the host rock or in the Fe dissolved in the water. Nevertheless, the relatively high Fe content in magnesite, mainly in the Talayuelas section, indicates that it precipitated under reducing conditions.

As in dolomite, magnesite has negative $\delta^{13}$ Cvalues (Fig. 8), probably reflecting the original ${ }^{13} \mathrm{C}$ composition of the carbonate precursor. However, the oxygen isotope values are different in Talayuelas and Landete sections. As observed in dolomite isotopic data, the values obtained in magnesite from Talayuelas section are similarly more negative than those from Landete area (Fig. 8).

If it is assumed that magnesite precipitated from a fluid with similar oxygen isotopic composition at the three localities, as suggested from their perographic and elemental geochemical similarities, then it is possible to calculate the differences in the temperature of magnesite precipitation between Iandete and Talayuelas sites. It should be noted that the different $\mathrm{Fe}$ content of magnesites would not significantly affect the variability of the $\delta^{18} \mathrm{O}$ values because of the similarities of the fractionation equations for magnesite $\left(10^{3} \ln \alpha_{\text {mg-w }}=3.13^{*} 10^{6} \mathrm{~T}^{-2}-\right.$ 3.02, Spötl and Burns, 1994) and siderite $\left(10^{3} \ln \alpha_{\mathrm{sd}-\mathrm{w}}=3.13^{*} 10^{6} \mathrm{~T}^{-2}-\right.$ 3.5, Carothers et al., 1988). Plotting the $\delta^{18} \mathrm{O}$ values of magnesite (in VPDB) versus temperature for several $\delta^{18} \mathrm{O}$ values of the water (in VSMOW), derived from the fractionation equation $10^{3} \ln \alpha_{\text {mg-w }}=$ 3.13* $10^{6} \mathrm{~T}^{-2}-3.02$ (Spötl and Burns, 1994), the range of possible temperatures of precipitation of magnesite at the two localities can be estimated (Fig. 10B). The highest precipitation temperature of magnesite would have been reached at Talayuelas area, where magnesite would have precipitated from fluids at temperatures around $8{ }^{\circ} \mathrm{C}$ warmer than at Iandete. This difference in the temperature of magnesite precipitation is similar to the difference of precipitation temperature of dolomite in these two localities, which was $9{ }^{\circ} \mathrm{C}$ warmer in Talayuelas than in Landete section (Fig. 10A).

Moreover, because magnesite replaces dolomite and precipitated during progressive burial, it can be assumed that magnesite precipitated at higher or at least at similar temperatures as dolomites at the same localities, that is, at temperatures of $60^{\circ}$ or lower at the Talayuelas and Landete sections, respectively (Fig. 10A). Thus, if a minimum temperature of $60^{\circ} \mathrm{C}$ is assumed for magnesite precipitation, on this basis, one can estimate that the oxygen isotopic composition of the water must have been heavier than $-2.5 \%$ VSMOW (Fig. 10B). Note, that even though the $\delta^{18} \mathrm{O}$ values obtained for the waters from which magnesite precipitated are less precise, are similar to those obtained from dolomite.

\subsection{Controls on precipitation temperature and origin of fluids}

As demonstrated above, dolomite likely precipitated during the shallowburial of the Permian Alcotas Formation. In this burial setting, it 
is important to evaluate the type of fluids required for dolomite precipitation. It has been demonstrated that at temperatures above $60{ }^{\circ} \mathrm{C}$ most Ca-rich groundwater could be dolomitizing fluids (Hardie, 1987); specifically, dolomite is stable in high-salinity brines with $\mathrm{Mg} / \mathrm{Ca}$ ratio around 1 at $50{ }^{\circ} \mathrm{C}$ Such $\mathrm{Mg} / \mathrm{Ca}$ ratios are, in turn, typical in groundwater from basinal brines in sedimentary rocks (Hardie, 1987). However, precipitation of magnesite requires higher $\mathrm{Mg} / \mathrm{Ca}$ molar ratios and/or higher temperatures (Hardie, 1987). Moreover, at relatively low temperatures precipitation of magnesite requires solutions of very high ionic strength, as hypersaline brines, which increase dehydration of $\mathrm{Mg}^{2+}$ making it more available for reaction (Purvis, 1989; Usdowsli, 1994).

As previously mentioned, oxygen isotope data indicate that dolomite probably precipitated from a fluid with an oxygen isotopic composition ranging between -0.3 and $-2.9 \%$ VSMOW, and magnesite precipitated from fluids with $\delta^{18} \mathrm{O}$ values more positive than $-2.5 \%$. VSMOW (Fig. 10A-B). These isotopic values are more positive than those typical of meteoric waters (e.g. Bowen and Wilkinson, 2002; Hoefs, 2004). In general, the isotopic composition of groundwater is similar to that of the rainfall water in the area of recharge, and in temperate and humid climates, rainfall water has more negative $\delta^{18} \mathrm{O}$ values, compared to seawater isotopic values (Hoefs, 2004). Thus, it is difficult to support that dolomite and magnesite precipitated from the Permian meteoric groundwater, because the sedimentary environment of the Alcotas Formation was alluvial, and meteoric waters have typically more negative $\delta^{18} \mathrm{O}$ values and also low $\mathrm{Mg} / \mathrm{Ca}$ ratios (Hanor, 1994a,b). Moreover, it is plausible to assume that Pemian to Triassic meteoric waters were more negative than -4 or $-5 \%$. VSMOW because the $\delta^{18} \mathrm{O}$ values of the Permian and the Triassic marine carbonates at low latitudes, as the Iberian Plate was during the Permian and Triassic times (Osete et al., 1997; Stampfli and Borel, 2002), ranged from -7 to $-2 \%$ VPDB (Prokov et al., 2008).

Spötl and Burns (1994) proposed the derivation of magnesite precipitated in the Permian redbeds of Austria from saline groundwater with low sulphate and high $\mathrm{Mg} / \mathrm{Ca}$ ratios. They considered the weathering of Devonian dolostones and associated magnesite deposits in the catchment area as the source for the high $\mathrm{Mg}$ content. However, no such carbonate deposits are present in the catchment area of this part of the Iberian Basin, where the basement is composed of quartzites and shales (Carls, 1988; Storch and Gutierrez-Marco, 1998).

Another possible source for the saline to hypersaline waters with appropriate isotopic composition could be the reflux of brines from the overlying Muschelkalk facies, constuted by shallow marine and sabkha deposits, and/or Keuper facies, mainly constituted by evaporites in the study area (Fig. 2). In this sense, Purvis (1989) and Rossi et al. (2002) have proposed the reflux of hypersaline brines from overlyingevaporite units for magnesite precipitation in Permian and Triassic continental deposits of the North Sea and Algeria, respectively. The Sr isotopic values of the studied dolomite and magnesite, however, are largely radiogenic (Fig. 8B) suggesting a non-marine origin. This can be explained if it is considered that dolomite and magnesite replace carbonates and clays precipitated and/or deposited in an alluvial environment, with largely radiogenic $\mathrm{Sr}$ isotopic compositions (Fig. $8 \mathrm{~B}$ ). Thus, fluids that led to precipitation of dolomite and magnesite could come via reflux of brines from the overlying Muschelkalk and Keuper facies, with much lower ${ }^{86} \mathrm{Sr} /{ }^{87} \mathrm{Sr}$ values (Korte et al., 2003; Fig. 8B); however, the $\mathrm{Sr}$ isotopic values of dolomite and magnesite would reflect, principally, locally-derived radiogenic Sr from the Alcotas Formation, which were replaced by dolomite and/or magnesite. The same occurred with the $C$ isotopic composition due to the water-rock interaction during dolomite and magnesite precipitation.

Another important question is the temperature of precipitation of dolomite and magnesite in the different locations. The Alcotas Formation was shallowly buried when dolomite precipitated, as demonstrated by petrographic features. However, the temperatures inferred for dolomite precipitation at the Henare jos section, based on the oxygen stable isotopes (Fig. 10A) and the saddle habit, are too high for shallow burial if this region was characterised by a normal geothermal gradient of $20-30^{\circ} \mathrm{C} / \mathbf{l m}$ (Allen and Allen, 2005). In order to reach $60^{\circ} \mathrm{C}$ at the Henare jos area a minimum burial of around 1.5$2 \mathrm{~km}$ would be necessary. At that depth fine-grained sandstone, siltstone and mudstone would have been already compacted (e.g. Wilson, 1994). However, petrographic features demonstrate that dolomite precipitated prior to or during the first stages of mechanical compaction. Thus, temperatures of up to $60{ }^{\circ} \mathrm{C}$ could not have been attained through burial alone. Moreover, burial history at the three localities was very similar (Fig. 3; Vargas et al., 2009), so burial alone cannot explain the differences in temperatures of dolomite precipitation obtained for the three localities, which are up to $25^{\circ} \mathrm{C}$ between Henare jos and Landete areas (Fig. 10A).

As pointed out above, the Alcotas Formation was deposited in semiconnected half-grabens during an early phase of the Permian-Triassic riftingstage and the three stratigraphic sections studied were situated in two of these semi-connected half-grabens (Fig. 1A). The Henarejos section was much closer to the NW-SE basin boundary fault than the other two sections, and the Talayuelas section was relatively closer than the Landete section to the secondary fault that separates both halfgrabens (Fig. 1A). Previous studies have demonstrated that regions of high heat flow on the continents generally correspond to active volcanic areas or to regions of extensional tectonics (Allen and Allen, 2005) and that most hydrothermal systems discharging at the land surface are associated with faulting, and that the location, temperature and rate of discharge of these systems are governed by the geometry and style of the controlling faults (Fairley, 2009). In this sense, recent results obtained in the Iberian Peninsula demonstrate that an important thermal resetting took place during the break-up of Pangea, with the most important period of resetting occurring at around $200 \mathrm{Ma}$, that is, during Late Triassic-Early Jurassic (Juez-Larre and Ter Voorde, 2009). These authors also show that active rifing combined with shallow magmatism, and to a lesser extent deep sedimentary burial, could have led to an increase of the geothermal gradient up to $73{ }^{\circ} \mathrm{C} / \mathrm{km}$. Thus, the successive periods of Mesozoic rifting connected to the break-up of Pangea significantly affected the thermal field of the Iberian crust at a regional and local scale (Juez-Larre and TerVoorde, 2009). It is possible, therefore, that saline fluids coming from the overlying Middle-Upper Triassic rocks via reflux, were heated as they passed through the extensional faults. Thus, fluids close to the Henare jos area would have been heated at higher temperatures than those at the Talayuelas and Landete areas, which were situated further away from the basin boundary fault (Fig. 1). Fluids in Talayuelas, in turn, would have been heated at higher temperatures than in Iandete. This appears to be related to the closer location of Talayuelas section to one of the transfer faults that connected adjacent half-grabens (Fig. 1).

\section{Conclusions}

Carbonate paleosols developed in the Middle-Upper Permian Alcotas Formation have been studied in three stratigraphic sections: Landete, Talayuelas and Henarejos. The Alcotas Formation was deposited in semiconnected half-grabens formed during the PermianTriassic rifting stage underwent by the Iberian Basin. The Henarejos section is closer to the basin boundary fault than the other two sections.

The original mineralogy of paleosols is not preserved because the carbonate precursors were replaced by dolomite and/or magnesite. Petrographic and geochemical data of dolomite in the three studied sections are very similar and reveal that dolomitisation occurred during the shallow burial. Nonetheless, dolomite in the Henarejos section frequently displays non-planar saddle habit, suggesting that the minimum temperature of dolomite precipitation at this locality was higher than $60{ }^{\circ} \mathrm{C}$. Additionally the $\delta^{18} \mathrm{O}$ values of dolomite from the Henarejos section are more negative than those obtained in the Talayuelas and Landete sections. Assuming that dolomite precipitated 
from a fluid with similar oxygen isotopic composition at the three localities studied, dolomite would have precipitated in the Talayuelas and Landete sections, at temperatures around 16 and $25{ }^{\circ} \mathrm{C}$ lower than in the Henare jos section, respectively. The $\delta^{18} \mathrm{O}$ values obtained for the dolomitizing fluid would have ranged between -0.3 and $-2.9 \%$ VSMOW.

Magnesite has been observed only in the Landete and Talayuelas sections and precipitated during the progressive burial but prior to chemical compaction. Assuming that magnesite precipitated from a fluid with the same oxygen isotopic composition in the two localities, magnesite would have precipitated at temperature around $8{ }^{\circ} \mathrm{C}$ higher in the Talayuelas than in the Landete section. The $\delta^{18} \mathrm{O}$ values obtained for the water are similar to those obtained from dolomite data.

Dolomitisation and magnesite precipitation occurred prior to or during mechanical compaction and probably via reflux of saline to hypersaline brines from the overlying Mid-Late Triassic Muschelkalk facies (composed of shallow carbonate marine and sabkha deposits) and/or Keuper facies (mainly composed of evaporites, marls and lutites). The temperatures inferred for dolomite precipitation, however, are too high for shallow burial if a normal geothermal gradient is applied. Thus, it seems reasonable to infer that saline fluids were heated as they passed through the syn-sedimentary extensional faults, which controlled Permian and Triassic sedimentation. Thus, fluids close to the Henarejos area would have been heated at higher temperatures than those at the Talayuelas and Landete areas, which were situated further away from the basin boundary fault. This is in agreement with recent results obtained in the Iberian Peninsula which point to an important thermal event during Late Triassic-Early Jurassic times (Juez-Larre and Ter Voorde, 2009).

\section{Acknowledgements}

Funds for this study were provided by the Ministerio de Ciencia e Innovación of Spain (project No. CGL 2008-00093BTE) and the Basins Research Group of the University Complutense of Madrid. The authors thank Simon Botrell and Bernard Bourdon for their revision on an earlier version of the paper and appreciate comments of Ana Alonso-Zarza and an anonymous reviewer. Gilberto Herrero, Beatriz Moral, Lora Wingate, Alfredo Fernández y Chema Fuenlabrada are acknowledged for their technical support.

\section{References}

Allen, P.A., Allen, J.R., 2005. Basin Analysis: Principles and Applications, 2nd ed. Blackwell, Oxford. $549 \mathrm{pp}$

Alonso-Azcárate, J., Arche, A., Barrenechea, J.F., López-Gómez, J., Luque, F.J., Rodas, M. 1997. Palaeogeographical significance of clay mineral assemblages in the Permian and Triassic sediments of the SE Iberian Ranges, eastern Spain. Palaeogeography Palaeoclimatology Palaeoecology 136, 309-330.

Alonso-Zarza, A.M., Sopeña, A., Sánchez-Moya, Y., 1999. Contrasting palaeosol development in two different tectonic settings: the Upper Buntsandstein of the western Iberian Ranges, Central Spain. Terra Nova 11, 23-29.

Arche, A., López-Gómez, J., 1996. Origin of the Permian-Triassic Iberian Basin, centraleastern Spain. Tectonophysics 266, 443-464.

Arche, A., López-Gómez,J., 1999. Tectonic and geomorphic controls on the fluvial styles of the Eslida Formation, Middle Triassic, Eastern Spain. Tectonophysics 315 $187-207$

Arche, A., López-Gómez, J., 2005. Sudden changes in fluvial style across the PermianTriassic boundary in the eastern Iberian Ranges, Spain: analysis of possible causes. Palaeogeography, Palaeoclimatology, Palaeoecology 229, 104-106.

Benito, M.I., DelaHorra, R, Barrenechea,J.F., López-Gómez, J., Rodas, M., Alonso Azcárate, J., Arche, A., Luque, F.J., 2005. Iate Permian in the SE Iberian Ranges, eastern Spain: petrological and mineralogical characteristics and palaeoenvironmental significance. Palaeogeography Palaeoclimatology Palaeoecology 229, 24-39.

Bourquin, S., Durand, M., Diez, J.B., Broutin, J., Fluteau, F., 2007. The Permian-Triassic boundary and Early Triassic sedimentation in Western European basins: an overview. Journal of Iberian Geology 33, 221-236.

Bowen, G.J., Wilkinson, B.H., 2002. Spatial distribution of $\mathbf{~}^{\mathbf{1}} \mathrm{O}$ in meteoric precipitation. Geology 30, 315-318.

Calvet, F., López-Gómez, J., Galindo, M.E., Tucker, M.E., Arche, A., 2001. Dolomías de gran escala en las plataformas epeíricas triásicas del este de la Península. Geotemas 3, 105-107. Europe. In: McMillan, N.J., Embry, A., Glass, D.J. (Eds.), Devonian of the World Canadian Society of Petroleum Geologists: Memoir, 14 (1), pp. 241-266. Calgary.

Carothers, W.W., Adami, L.H., Rosenbauer, R.J., 1988. Experimental oxygen isotope fractionation between siderite-water and phosphoric acid liberated $\mathrm{CO}_{2}$-siderite Geochimica et Cosmochimica Acta 52, 2445-2450.

Chang, L.L.Y., Howie, RA., Zussman,J., 1996. An Introduction to the Rock-Forming Minerals. Volume 5B: Non-silicates: Sulphates, Carbonates, Phosphates and Halides. Ed. Iongman. Essex. England, $383 \mathrm{pp}$.

De la Horra, R., 2008. Variaciones mineralógicas, geoquímicas y bióticas del Pérmico Superior en el Sudeste de la Cordillera Ibérica: Implicaciones paleogeográficas y paleoclimáticas. Ph.D. Thesis, University Complutense of Madrid, Spain.

De la Horra, R., Benito, M.I., López-Gómez, J., Arche, A., Barrenechea, J., Luque, J., 2008. Paleoenvironmental significance of Late Permian paleosols in the SE Iberian Ranges, Spain. Sedimentology 55, 1849-1873.

Deelman, J.C., 2008. Iow-temperature formation of dolomite and magnesite. A comprehensive revision. version 2.2. Compact Disc Publications. : Geology Series. Compact Disc Publications, Eindhoven, The Netherlands http:/www.jcdeelman demon.nl/dolomite/Oookprospectus.html 515 pp.

Dickson, J.A.D., 1966. Carbonate identification and genesis as revealed by staining. Journal of Sedimentary Petrology 36, 491-505.

Doubinger, J., López-Gómez, J., Arche, A., 1990. Pollen and spores from the Permian and Triassic sediments of the southeastern Iberian Ranges, Cueva de Hierro (Cuenca) to Chelva-Manzanera (Valencia-Teruel) region, Spain. Review of Paleobotany and Palynology 66, 25-45.

Fairley,J.P., 2009. Modeling fluid flow in a heterogeneous, fault-controlled hydrothermal system. Geofluids $\mathbf{9}, 153-166$

Fritz, P., Smith, D.G.W., 1970. The isotopic composition of secondary dolomites. Geochimica et Cosmochimica Acta 34, 1161-1173.

Gómez-Gras, D., Alonso-Zarza, A.M., 2003. Reworked calcretes: their significance in the reconstruction of alluvial sequences (Permian and Triassic, Minorca, Balearic Islands, Spain). Sedimentary Geology 158, 299-319.

Gregg, J.M., Sibley, D.F., 1984. Epigenetic dolomitization the origin of xenotopic dolomite texture. Journal of Sedimentary Petrology 54, 907-931.

Hanor, J.S., 1994a. Physical and chemical controls on the composition of waters in sedimentary basins. Marine and Petroleum Geology 11, 31-45.

Hanor, J.S., 1994b. Origin of saline fluids in sedimentary basins. In: Parnell, J. (Ed.) Geofluids: Origin and migration of fluids in sedimentary basins. Geological Society of Iondon Special Publication 78, pp. 151-174.

Hardie, L.A., 1987. Dolomitization: a critical view of some current views. Journal of Sedimentary Petrology 57, 166-183.

Hoefs, J., 2004. Stable Isotope Geochemistry, 5th ed. Springer, Berlin. 201 pp.

Juez-Larre, J., Ter Voorde, M., 2009. Thermal impact of the break-up of Pangea on the Iberian Peninsula, assessed by thermochronological dating and numerical modelling. Tectonophysics 474, 200-213.

Korte, C., Kozur, H.W., Bruckschen, P., Veizer, J., 2003. Strontium isotope evolution of Iate Permian and Triassic seawater. Geochimica et Cosmochimica Acta 67, 47-62.

Lohmann, K.C., 1987. Geochemical patterns of meteoric diagenetic systems and their application to studies of palaeokarst. In: James, N.P., Choquette, P.W. (Eds.), Palaeokarst. Springer-Verlag, Berlin, pp. 58-80.

López-Gómez,J., 1985. Sedimentologíay estratigrafiadelos materiales pérmicos y triásicos del SE de la Rama Castellana de la Cordillera Ibérica entre Cueva de Hierro y Chelva (provincias de Cuenca y Valencia). Seminarios de Estratigrafia, 11. Madrid.

López-Gómez, J., Arche, A., 1993. Sequence stratigraphy analysis and paleogeographic interpretation of the Buntsandstein and Muschelkalkfacies (Permo-Triassic) in the SE Iberian Ranges, eastern Spain. Palaeogeography Palaeoclimatology Palaeoecology 103, 347-361.

López-Gómez, J., Arche, A., 1997. Late Permian Boniches Conglomerates Formation: evolution from alluvial fans to fluvial systems environments and accompanying tectonic and climatic controls in SE Iberian Ranges. Sedimentary Geology 114 $267-294$

López-Gómez, J., Arche, A., Pérez-López, A., 2002. Permian and Triassic. In: Gibbons, W., Moreno, T. (Eds.), The Geology of Spain: Geological Society of London. Special Publication, pp. 185-212.

López-Gómez, J., Dela Horra, R., Benito, M.I., Barrenechea, J.F., Arche, A., Luque, F.J., AlonsoAzcárate, J., Diéguez, C., Rodas, M., 2005. Characteristics of the Upper Permian continental sediments and their relationship with the end Permian crisis in Southern Iberian Ranges, Spain. New México Museum Natural History \& Science Bulletin 30 , $172-178$.

López-Gómez, J., Arche, A., Vargas, H., Marzo, M., 2010. Fluvial architecture as a response to two-layerlithospheric subsidence during the Permian and Triassicin the Iberian Basin, eastern Spain. Sedimentary Geology 223, 320-333.

Mack, G.H., James, W.C., Monger, H.C., 1993. Classification of paleosols. Bulletin of the Geological American Society 105, 129-136.

Möller, P., 1989. Magnesite: genesis, mineralogy, geochemistry. Formation of MgCarbonates: Monograph Series on Mineral Deposits, 28. 300 pp.

Niedermayr, G., Beran, A., Brandstätter, F., 1989. Diagenetic typemagnesites in the PermoScythian rocks of the Eastern Alps, Austria. In: Möller, P. (Ed.), Magnesite: Genesis, Mineralogy, Geochemistry. Formation of Mg-Carbonates: Monograph Series on Mineral Deposits, 28, pp. 35-59.

Osete, ML, Rey, D., Villalaín, J.J., Juarez, M.T., 1997. The Iate Carboniferous to Iate Triassic segment of the apparent polar wander path of Iberia. Geologie en Mijnbouw 76, 105-11s.

Pérez-Arlucea, M., 1985. Estratigrafia y sedimentología del Pérmico y Triásico en el sector Molina de Aragón-Albarracín (provincias de Guadalajara y Teruel). Ph. D. Thesis. University Complutense of Madrid. Madrid. 
Pohl, W., 1990. Genesis of magnesite deposits - models and trends. Geologische Rundschau 79 (2), 291-299.

Prokov, A., Shields, GA., Veizer,J., 2008. Compilation and time-series analysis of a marine carbonate $6^{18} \mathrm{O}, 6^{13} \mathrm{C},{ }^{87} \mathrm{Sr} /{ }^{26} \mathrm{Sr}$ and $6^{34} \mathrm{~S}$ database through Earth history. Earth-Science Reviews 87, 113-133.

Purvis, K., 1989. Zoned authigenic magnesites in the Rotliegend Iower Permian, southern North Sea. Sedimentary Geology 65, 307-318.

Purvis, K., 1992. Iower Permian Rotliegend sandstones, southern North Sea: a case study of sandstone diagenesis in evaporite-associated sequences. Sedimentary Geology 77 , $155-171$.

Radke, B.M., Mathis, R.L., 1980. On the formation and occurrence of saddle dolomite. Journal of Sedimentary Petrology 50, 1149-1168.

Ramos, A., 1979. Estratigrafia y paleogeografia del Pérmico y Triásioo al oeste de Molina de Aragón (Provincia de Guadalajara). Seminarios de Estratigrafia: Serie Monografias, 6. Madrid.

Ramos, A., Sopeña, A., Pérez-Arlucea, M., 1986. Evolution of Buntsandstein fluvial sedimentation in Northwest Iberian Ranges (Central Spain). Journal of Sedimentary Petrology 56, 862-875.

Rossi, C., Kälin, O., Arribas, J., Tortosa, A., 2002. Diagenesis, provenance and reservoir quality of Triassic TAGI sandstones from Ourhold field, Berkine (Ghadames) Basin, Algeria. Marine and Petroleum Geology 19, 117-142.

Salas, R., Casas, A., 1993. Mesozoic extensional tectonics, stratigraphy and crustal evolution during the Alpine cycle of the Eastem Iberian Basin. Tectonophysics 228, 33-55.

Sopeña, A., López, J., Arche, A., Pérez-Arlucea, M., Ramos, A., Virgili, C., Hernando, S. 1988. Permian and Triassic rift basins of the Iberian Peninsula. In: Manspeizer, $W$. (Ed.), Triassic-Jurassic Rifting. : Developments in Geotectonics, 22. Elsevier, New York, pp. 757-784

Sopeña, A., Doubinger, J., Ramos, A., Pérez-Arlucea, M., 1995. Palynologie du Permian et du Trias dans le Centre de la Péninsule Ibérique. Sciences Géologique. Bulletin 48, 119-157.
Spötl, C., Burns, S.J., 1994. Magnesite diagenesis in redbeds: a case study from the Permian of the Northern Calcareous Alps (Tyrol, Austria). Sedimentology 41, 543-565.

Spötl, C., Pitman,J.K., 1998. Saddle (baroque) dolomite in carbonates and sandstones: a reppraisal of a burial-diagenetic concept. In: Morad, S. (Ed.), Carbonate Cementation in Sandstones: Special Publication of the International Association of Sedimentologists, 26 , pp. 437-460.

Stampfli, G.M., Borel, G.D., 2002. A plate tectonic model for the Paleozoic and Mesozoic constrained by dynamic plate boundaries and restored synthetic oceanic isochrones. Earth and Planetary Science Ietters 196, 17-33.

Storch, P., Gutierrez-Marco, J.C., 1998. Silurian sections of the Castillian Branch of the Iberian Cordillera (provinœes of Guadalajara and Teruel). Temas Geológico-Mineros ITGE 23, 326-335.

Usdowski, E, 1994. Synthesis of dolomite and geochemical implications. In: Purser, B., Tucker, M., Zenger, D. (Eds.), Dolomites: Special Publication of the International Association of Sedimentologists, 21, pp. 345-360.

Vargas, H., Gaspar-Escribano, J.M., López-Gómez, J., Van Wees, J.D., Cloetingh, S., De la Horra, R., Arche, A., 2009. A comparison of the Iberian and Ebro Basins during the Permian and Triassic, eastern Spain: a quantitative subsidence modelling approach. Tectonophysics 474, 160-183.

Visscher, H., 1971. The Permian and Triassic of the Kingscourt outlier, Ireland. A palynological investigation related to regional stratigraphical problems in the Permian and Triassic of Western Europe. Special Paper. Geological Survey Ireland 1, $1-114$

Warren, J., 2000. Dolomite: occurrence, evolution and economically important associations. Earth-Science Reviews 52, 1-81.

Wilson, M.D. (Ed.), 1994. Reservoir quality assesment and prediction in clastic rocks. SEPM Short Course 30. Tulsa. 432 pp. 